\title{
Nano-hydroxyapatite coating synthesized on quasi-fibrillar superstructures of collagen hydrolysate leads to superior osteoblast proliferation when compared to nano-hydroxyapatite synthesized on collagen fibrils
}

\author{
Pradipta Banerjee*, Mayur Bajaj ${ }^{1}$, Chetna Bhat ${ }^{2}$, Geethika $\mathrm{Y}^{2}$, Hemanth Irle ${ }^{2}$ \\ 1 - Department of Biological Sciences, \\ Indian Institute of Science Education and Research (IISER), \\ Tirupati - 517507, \\ Andhra Pradesh, India \\ 2- School of Basic and Applied Sciences, \\ Dayananda Sagar University \\ Bangalore - 560111, \\ Karnataka, India \\ *-Corresponding Author, \\ Assistant Professor of Biochemistry, \\ School of Basic and Applied Sciences, \\ Dayananda Sagar University, \\ Bangalore - 560111, \\ Karnataka, India \\ Phone: +91-9886429261 \\ Email: roon17779@gmail.com
}




\begin{abstract}
This study had a two-fold objective: To utilize collagen hydrolysate for synthesizing a nanoscale Hydroxyapatite (HA) coating that would act as a superior osteoblast adhesion/ proliferation agent compared to collagen-derived $\mathrm{HA}(\mathrm{C} / \mathrm{HA})$ and to comprehend the significant role played by structural constraints on HA nucleation. Collagen was extracted from pacu skin with a high yield of $65.3 \%$ (w/w of tissue). It was digested by collagenase and the hydrolysate $(\mathrm{CH})$ was purified with a high yield of $0.68 \mathrm{~g} / \mathrm{g}$ of collagen. The $\mathrm{CH}$ peptides had a mass of $6 \mathrm{kDa}$, a predominant PP-II conformation and formed self-assembling hierarchical structures at physiological $\mathrm{pH}$ with dimensions of $842.2 \pm 229 \mathrm{~nm}$. The HA synthesized on $\mathrm{CH}(\mathrm{CH} / \mathrm{HA})$ displayed higher yield when compared to $\mathrm{C} / \mathrm{HA}$. Structural analysis of $\mathrm{CH} / \mathrm{HA}$ revealed that the PP-II peptides coiled to form mimic-helical moieties with reduced intermolecular packing distance of $0.9 \mathrm{~nm}$. The mimic helices cross-linked to form a vast quasi-fibrillar network that was comparatively smaller than collagen fibrils but exhibited enhanced stability and greater dynamicity. $\mathrm{CH} / \mathrm{HA}$ displayed intense calciumcarboxyl interactions, sharper diffraction planes, smaller size of $48 \pm 6.2 \mathrm{~nm}$ and a $\mathrm{Ca} / \mathrm{P}$ ratio closer to 1.69 when compared to $\mathrm{C} / \mathrm{HA}$ along with displaying serrated edge blooming crystals. Because of the small size, the $\mathrm{CH} / \mathrm{HA}$ nanocrystals displayed significantly better osteoblast adhesion than $\mathrm{C} / \mathrm{HA}$ and reduced the doubling time of cells. Overall, the results indicated that $\mathrm{CH}$ based nanocomposites displayed suitable morphological characteristics and cellular response for potential application as implant and bone graft coating material.
\end{abstract}

Keywords - Nanocrystals, Hydroxyapatite Coating, Collagen Hydrolysate, PP-II helix, Quasi-fibril, Osteoblast adhesion 


\section{Introduction}

Orthopedic implants are an effective treatment to repair fractures and replace lost portions of bone tissue. [1]. However, a substantial number of implants fail to integrate with host bone owing to their inability to activate osteoblast proliferation, leading to a considerable number of rejections and revision surgeries [2,3]. A customary technique of constructing hostfriendly endosseous metal components involves coating the surface with a bioactive and osteoconductive material like hydroxyapatite $(\mathrm{HA})\left[\mathrm{Ca}_{10}\left(\mathrm{PO}_{4}\right)_{6}(\mathrm{OH})_{2}\right][2,4]$. However, chemically synthesized HA displays deformed crystals, low tensile strength, and a variable composition depending on its scheme of synthesis, consequently leading to incoherent comparing parameters $[5,6]$.

Biomimetic strategies offer a simple and effective solution to create HA [7]. The procedure requires suspension of a protein substratum, generally collagen type-I, in a HA nucleating solution allowing in vitro crystal formation. The reaction process is easy to control and offers a high yield. Even though the method has been known for over a decade, the exact mechanism of in vitro HA nucleation is yet to be deciphered in its entirety [8]. Knowing the mechanism is imperative as it will allow high-throughput synthesis of HA with dimensions similar to bone crystals, which, when coated on medical implants, will guide faster osteoblast adhesion, leading to effective osseointegration.

The current theories that attempt to decipher biomineralization can be divided roughly into two doctrines. One school of thought pursues that the presence of negatively charged groups is sufficient for biomineralization to occur. In this theory, the presence of acidic residues or carboxyl groups is sufficient to nucleate HA, superseding the need for collagen or any structural hierarchy $[9,10,11]$. The studies that champion this thought process also suggest that in physiological conditions, nucleation is initiated by acidic residues from accessory proteins while collagen merely supplies the structural framework necessary for crystals to propagate [12]. The alternate theory considers the structural aspect of collagen Type-I to be of primary importance. It suggests that the triple-helical nature of collagen and its long fibrillar arrangement initiates and regulates the interaction between terminal amino acid residues and inorganic ions resulting in HA formation [13]. In this theory, the process of mineralization is heavily influenced by the secondary structure with amino acid sequence playing a comparatively less significant role $[14,15,16]$. 
It was clear from a thorough literature survey that an attempt by either process would lead to one result or the other but not a definitive solution. So, the authors tried a different approach by attempting to nucleate $\mathrm{HA}$ on collagen hydrolysate $(\mathrm{CH})$ instead of collagen. As of today, there exist only two studies that have mentioned HA nucleation on $\mathrm{CH}$. One among them lists the conditions that would allow $\mathrm{CH}$ from chrome tanning waste to nucleate HA [17]. However, the yield, dimensions, and osteophilicity of the crystals have not been reported. The other study reports the use of $\mathrm{CH}$, but only as an accessory source of carboxylic acid in the biomineralization of collagen [18].

Here, we report the first study on the bio-mimetic mineralization efficacy of fish collagen hydrolysate in the absence of any accessory proteins. We show that the constituent peptides of collagen hydrolysate are self-sufficient in initiating and orienting the formation of carbonated HA in vitro in a manner that is similar to bone formation in the body. We also report that $\mathrm{CH}$ is significantly more efficient than collagen in producing HA crystals that possess sharper crystal planes and are smaller in dimensions leading to higher osteoblast adhesion and proliferation. The results obtained in this study provides substantial insight into the mechanism of HA nucleation and help in understanding the conditions governing in vitro biomineralization. Consequently, this leads to a deeper understanding of the in vivo HA nucleation process, opening up pathways to synthesize protein-HA composites with smaller dimensions and higher osseointegration properties to be used as coating on medical implants.

\section{Materials and Methods}

The collagen used for this study was collected from fish processing by-products. The chemicals utilized in the experiments were procured from Himedia Labs Pvt Ltd., Mumbai. Collagenase type-I enzyme was purchased from Juniper life sciences, Bangalore. Antimycotic/Antibiotic solution and Glutaraldehyde grade 1 were procured from Sigma Aldrich.

\subsection{Isolation of collagen}

The fish species to be used for collagen extraction was chosen based on a market survey along with an analysis of FAO reports. Red-bellied Pacu is one of the fastest-growing freshwater fish species released in India [19,20]. During the time of the study, it was sold in high demand in local markets and hence its processing by-products were chosen for the 
source of collagen extraction. Descaled skin samples were collected from a nearby local market, brought to the University, washed and dry weight of the material was noted. Acid soluble collagen was extracted following a standard protocol [21]. The extraction involved successive treatments by $5 \% \mathrm{NaOH}, 5 \%$ butanol, and $0.25 \%$ EDTA to remove noncollagenous proteins, fats, and minerals respectively with dry weight being noted between every successive treatment. The post-treatment material was dissolved in $0.5 \mathrm{M}$ acetic acid for 36 hours with regular changes of the solution. This cycle was conducted repeatedly to extract the maximum amount of collagen. The extracts were pooled and collagen was precipitated by adding 6\% (w/v) $\mathrm{NaCl}$. The precipitated collagen was desalted by dialysis against deionized water for $72 \mathrm{hrs}$ and dried in a VD-250R Freeze dryer (Taitec, Japan).

\subsection{Hydrolysis of collagen and purification of $\mathrm{CH}$}

The lyophilized collagen sample was subjected to fragmentation using bacterial collagenase. Collagenase type-I was dissolved in $0.1 \mathrm{M}$ phosphate buffer, $\mathrm{pH} 7.2$, at a concentration of $4 \mathrm{mg} \mathrm{ml}^{-1}$. This was added to a solution of collagen $\left(100 \mathrm{mg} \mathrm{ml}^{-1}\right)$ dissolved in an identical buffer system. The reaction mixture was incubated at $37^{\circ} \mathrm{C}$ for $24 \mathrm{hrs}$. The solution was centrifuged at $5000 \mathrm{rpm}$ at $6^{\circ} \mathrm{C}$ for $15 \mathrm{~min}$ to remove any suspended debris. The supernatant was mixed with acetate buffer, $\mathrm{pH} 4.5$, and applied to a $1.5 \times 5 \mathrm{~cm}$ CM Sepharose column attached to a low-pressure automated chromatography unit. The sample was eluted with a linear gradient of $\mathrm{NaCl}$ ranging from 0 to $1 \mathrm{M}$. Fractions representing the eluted samples were pooled and applied to a $1.5 \times 3 \mathrm{~cm}$ PD-10 column. Deionized water was run, and desalted $\mathrm{CH}$ sample was collected. The pooled sample was freeze-dried to obtain a powder.

\subsection{Structural attributes of $\mathrm{CH}$}

\subsubsection{SDS-PAGE of CH}

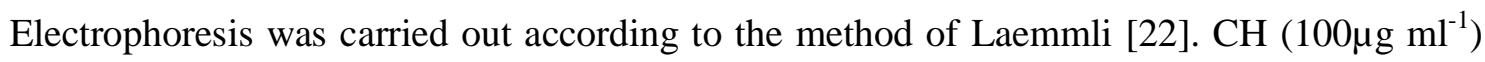
was run in an $8 \%$ resolving gels. Intact skin collagen, rat-tail tendon collagen, and known molecular weight markers were run under similar conditions for reference. The gels were stained as per standard protocols [23].

\subsubsection{Folding studies on $\mathrm{CH}$}

The stability of $\mathrm{CH}$ was checked by measuring the $\mathrm{pH}$-induced shift of the $230 \mathrm{~nm}$ peak. The samples were dissolved at a concentration of $10 \mu \mathrm{g} \mathrm{ml}^{-1}$ in $0.1 \mathrm{M}$ of numerous buffer systems, including acetate ( $\mathrm{pH} 4$ and 5), citrate ( $\mathrm{pH}$ 6), phosphate (pH 7 and 8), and tris buffer ( $\mathrm{pH} 9$ ). 
Absorbance spectra were analyzed by scanning in the range of 200-400nm using a Genesys 10S UV-Vis Spectrophotometer (Thermo). Collagen was used as control.

\subsubsection{Zeta potential and dimensions of $\mathrm{CH}$}

A Nanotrac wave II Q was used to measure the zeta potential and dimensions of $\mathrm{CH}$ in $0.1 \mathrm{M}$ phosphate-buffered saline, $\mathrm{pH}$ 7.4. Background measurement was performed using only buffer. Collagen was used as control.

\subsubsection{Circular Dichroism studies on CH}

$\mathrm{CD}$ studies were conducted to determine the effect of $\mathrm{pH}$ on the secondary structure. $\mathrm{CH}$ was dissolved in $0.1 \mathrm{M}$ phosphate buffer, $\mathrm{pH} 7.4$ at a concentration of $2 \mathrm{mg} \mathrm{ml}^{-1}$. The solutions were centrifuged at $8000 \mathrm{rpm}$ for $1 \mathrm{~min}$ to obtain a clear supernatant. $400 \mu 1$ of the supernatant was loaded into a quartz cylindrical cuvette with a path length of $1 \mathrm{~mm}$. A Jasco J-715 spectropolarimeter was used to carry out the spectral analysis. Collagen, treated similarly, was used as control.

\subsection{Biomimetic growth of HA crystals on $\mathrm{CH}$}

HA crystals were bio-mimetically synthesized on $\mathrm{CH}$ by following the protocol of Banerjee et al. [17]. CH (500 mg) was suspended in a solution containing $100 \mu \mathrm{mol} \mathrm{ml}^{-1}$ of $\mathrm{NaCl}$ and $10 \mu \mathrm{mol} \mathrm{ml}{ }^{-1}$ of $\mathrm{Na}_{2} \mathrm{HPO}_{4}$. 20 sets were made. Each set was sealed after adding 150 $\mu 1$ of 1:10 diluted antimycotic solution and $2.8 \mu \mathrm{l}$ of glutaraldehyde grade $1\left(25 \%\right.$ in $\left.\mathrm{H}_{2} \mathrm{O}\right)$. After 24 hours, $20 \mu \mathrm{mol}$ of $\mathrm{CaCl}_{2}$ dissolved in phosphate buffer of $\mathrm{pH} 7.4$ was added to all the sets. The tubes were re-sealed and incubated at $37^{\circ} \mathrm{C}$ for 31 days for crystal growth. The crystals were washed 6 times in distilled water and freeze-dried as before. The dried crystals were subjected to structural analysis. Crystals grown on collagen, treated similarly, were used as control samples. The composites were labelled as $\mathrm{CH} / \mathrm{HA}$ and $\mathrm{C} / \mathrm{HA}$ for $\mathrm{HA}$ synthesized on $\mathrm{CH}$ and collagen respectively.

\subsection{Characterisation of $\mathrm{CH} / \mathrm{HA}$ crystals}

\subsubsection{Photoluminescence profile of $\mathrm{CH} / \mathrm{HA}$}

Fluorescence intensities of $\mathrm{CH} / \mathrm{HA}$ were measured by a Cary Eclipse Fluorescence Spectrophotometer. The emission spectrum was detected at a voltage of $800 \mathrm{~V}$, in the range of $240-550 \mathrm{~nm}$ with a scanning rate of $300 \mathrm{~nm} \mathrm{~min}^{-1}$. 


\subsubsection{IR Spectral profile of $\mathrm{CH} / \mathrm{HA}$}

The functional groups of the crystals were profiled using Thermo Nicolet iS5 FT-IR. 200mg of $\mathrm{KBr}$ was ground with $1 \mathrm{mg}$ of $\mathrm{CH} / \mathrm{HA}$ crystals to form a translucent pellet. The pellet was utilized to read the transmittance profile at the IR range.

\subsubsection{XRD profile of $\mathrm{CH} / \mathrm{HA}$}

XRD analysis of $\mathrm{CH} / \mathrm{HA}$ was performed on Rigaku D/Max X-ray diffractometer with $\mathrm{Cu} \mathrm{K} \alpha$ radiation source (wavelength $=1.54 \AA$ ). The supplied voltage and current were set to $40 \mathrm{kV}$ and $120 \mathrm{~mA}$, respectively. The samples were exposed at a scan rate of $10^{\circ} \mathrm{min}^{-1}$ from $5^{\circ}$ to $60^{\circ}$.

\subsubsection{Zeta potential and dimensions of $\mathrm{CH} / \mathrm{HA}$}

A Nanotrac wave II Q was used to measure the zeta potential and size of $\mathrm{CH} / \mathrm{HA}$ samples. Background measurement was performed using water. The sample was suspended in deionized water and measurements were taken for 30sec. C/HA was used as control.

\subsubsection{SEM-EDX analysis of CH/HA}

SEM was performed on $\mathrm{CH} / \mathrm{HA}$ crystals to investigate their morphology and porosity. $\mathrm{CH} / \mathrm{HA}$ crystals were sputter-coated with gold and were observed under a field-emission scanning-electron microscope with a magnification of 1500X (S-4700, Hitachi Ltd., Tokyo, Japan). The interfaces were examined in secondary electron mode at $1 \mathrm{keV}$ accelerating voltage and 10mA emission current. SEM images were acquired digitally by a data acquisition system. Energy-dispersive X-ray spectroscopy (EDX) was used at specific locations to detect the Calcium/Phosphate ratio $(\mathrm{Ca}: \mathrm{P})$ and their distribution within the sample.

\subsubsection{Dimensional analysis of $\mathrm{CH} / \mathrm{HA}$}

The topological assessment and crystal size estimation was determined by atomic force microscopy (AFM). The crystals were dispersed in $50 \%$ ethanol and dispensed on a mica coverslip. The coverslip was placed inside a desiccator and left undisturbed until it dried. AFM analysis in Non-Contact Mode was conducted for the dried sample using an A-100 AFM (APE Research, Italy).

\subsection{Osteoblast adhesion/proliferation on $\mathrm{CH} / \mathrm{HA}$}


The osteosarcoma cell lines (MG-63) were cultivated according to the recommendation of the supplier, in DMEM containing 10\% FBS and $40 \mathrm{IU} \mathrm{ml}^{-1}$ of antibacterial and antimycotic solution. Cells were cultured in T25 flasks in a humidified $5 \% \mathrm{CO}_{2}$ incubator at $37^{\circ} \mathrm{C}$. For passaging, cells were detached with trypsin/EDTA and subsequently replated. Trypan blue exclusion assay was carried to check the viability of the cells and cell count was estimated using Neuber's chamber.

The test ( $\mathrm{CH} / \mathrm{HA})$ and control $(\mathrm{C}, \mathrm{CH}, \mathrm{C} / \mathrm{HA})$ samples, in triplicates, were coated on 48 well plates at an amount ranging from $10 \mu \mathrm{g}$ to $1 \mathrm{mg}$ per well. The plates were exposed to UV for 3 hours, followed by air-drying, rinsing with 0.1M PBS and re-drying. MG63 cells suspended in DMEM media were seeded on to the test and control wells at a count of $4 \times 10^{4}$ cells per well. The plates were kept in a $\mathrm{CO}_{2}$ incubator for $6 \mathrm{hrs}$ and cell adhesion measured by MTT assay.

Cell proliferation assay was conducted in triplicates. A fixed number of cells were added to the coated dishes and an MTT assay was conducted every $12 \mathrm{~h}$ for $72 \mathrm{~h}$. A calibration curve was prepared with a known cell count. The doubling time of the cells grown was calculated by fitting the curves to the exponential function given below by the least-squares method.

$$
Y=Y_{o} \times e^{(k * x)}
$$

where $\mathrm{Y}$ and $\mathrm{Y}_{0}$ signify the change in cell count with time and the cell count at time zero respectively, $\mathrm{x}$ denotes the time in hours and $\mathrm{k}$ is the rate constant to be determined, expressed in $\mathrm{h}^{-1}$. The doubling time $(\mathrm{t})$ was calculated by the equation:

$$
t=\frac{\ln 2}{k}
$$

The datasets were analyzed by two-way ANOVA with post hoc Tukey's Test. P values less than 0.05 were considered significant.

\section{Results and discussion}

\subsection{Isolation and Extraction of collagen}


Table 1 depicts the \% of acid-soluble collagen (ASC) extracted from the skin of Piaractus brachypomus (Red-Bellied Pacu). The extraction process yielded $65.3 \%$ of collagen. The results matched with collagen yield obtained from Catla and Rohu skin (65-69\%) [24] and was higher than most acid extraction techniques [25-29].

The efficiency of collagen extraction depends heavily on the extraction protocol and to some extent, on fish species, source tissue, and environmental conditions [30]. A large number of studies use pepsin along with acetic acid to increase the efficiency of extraction $[31,32]$. Pepsin cleaves the cross-linked telopeptides of collagen leading to better solubility and higher yield [30]. However, enzymatic treatment is costly and leads to bottlenecks in large scale extraction. At the same time, pepsin-mediated removal of telopeptides and associated sequences could lead to a loss of potential HA nucleating sequences. The higher yield obtained in this study, even without the use of pepsin, was due to specific modifications of the extraction protocol that included the use of milder $\mathrm{NaOH}$ during pre-treatment and repeated acetic acid extraction. Multiple cycles of ASC may appear as time-consuming, but it ensures greater extraction of intact collagen at a lower cost.

\subsection{Hydrolysis of Collagen type-I and Purification of $\mathrm{CH}$}

The complex hierarchy, steric crowding, and ample abundance of proline in collagen renders it insusceptible to complete degradation by digestive protease. Efficient degradation can only be possible through bacterial collagenolytic enzymes which cleave at specific repetitive sites [33]. The isolated collagen was fragmented by Collagenase type I-A from Clostridium histolyticum, which cleaves at the repeating sequence $\mathrm{P}-\mathrm{X}-\mathrm{G}-\mathrm{P}$ where $\mathrm{X}$ is a neutral amino acid.

The $\mathrm{CH}$ exhibited an elution profile as shown in Fig. 1a. A prominent peak was observed at $43.50 \% \mathrm{NaCl}$ for $\mathrm{CH}$. The higher ionic strength required for elution reflected the higher charge density of $\mathrm{CH}$ due to the increased number of free $\mathrm{N}$ and $\mathrm{C}$-terminals. Contrastingly, the control collagen sample eluted at $8.2 \%$ and $28 \% \mathrm{NaCl}$. The latter peak was attributed to the elution of $\alpha$ chains whereas the former small peak was attributed to higher-order structures formed by the recoiled $\alpha$-chains, a signature profile of collagen type-I. The $\mathrm{CH}$ yield was calculated to be $0.68 \mathrm{~g} / \mathrm{g}$ of collagen, which was comparatively higher than previous reports [27].

\subsection{Molecular weight profiling of $\mathrm{CH}$}


As shown in Fig. 1b, the electrophoretic pattern exhibited by the isolated collagen (Lane 1) matched with that of rat-tail tendon collagen (Lane 2), confirming it to be of type-I [34]. The unique recoiling nature of collagen is depicted in its signature electrophoretic profile with two prominent $\alpha$ bands, resulting from its twin $\alpha 1$ chains and single $\alpha 2$ chain, along with higher-order $\beta$ and $\gamma$ band [35]. The molecular weight (MW) of $\alpha 1$ and $\alpha 2$ bands corresponded to values of $125 \mathrm{kDa}$ and $110 \mathrm{kDa}$ respectively. The presence of the higher-order $\beta$ and $\gamma$ bands are attributed to recoiling of $\alpha$ chains with each other, a pattern also observed in the ion-exchange profile of collagen. Lane 3 depicted the enzymatic digest of collagen run under similar conditions. The $\mathrm{CH}$ was devoid of any $\alpha$ or higher-order profiles and displayed a low molecular weight band at the bottom of the gel. The MW, when compared to standard marker run under similar conditions (Lane 4), was determined to be around 6kDa with the possible presence of fractions with even lower MW.

\subsection{Structural attributes of $\mathbf{C H}$}

An intense peak at 220-230nm corresponds to the presence of amine groups in peptide bonds. This peak has been known to corroborate the structural state of the protein and indicates hierarchical assembly formation [36]. A hypsochromic shift of this peak with changing $\mathrm{pH}$ provides evidence of folding characteristics of biomolecules.

Fig. 2a exhibits the $\mathrm{pH}$-induced spectral shift of $\mathrm{CH}$. The profile can be compared with the folding tendencies of intact collagen type-I as shown in Fig. 2b. At pH 4, $\mathrm{CH}$ exhibited an absorbance maximum (or $\lambda_{\max }$ ) at $230 \mathrm{~nm}$ while collagen displayed a broad peak at $221 \mathrm{~nm}$. The difference in $\lambda_{\max }$ was attributed to the absence of folded states in $\mathrm{CH}$ [37]. Interestingly, upon changing the $\mathrm{pH}$ from 4 to $5, \mathrm{CH}$ underwent a blue shift indicating that its peptide components were able to orient themselves in a hierarchical proto-aggregated structure. Collagen retained its absorbance maxima and correspondingly, its structural state.

At $\mathrm{pH}$, both $\mathrm{CH}$ and collagen displayed low solubility and a redshift at $230 \mathrm{~nm}$. This was due to the fact that the $\alpha 1$ chain of collagen has a pI nearing 6 , rendering it with zero net charge and low solubility. This results in distortion of the proto-aggregated structures leading to the uncoiling of the components. Also, presence of the insoluble protein chain leads to scattering of incident wavelengths decreasing the signal-to-noise ratio of the spectrum.

A sharp blue shift was observed at $\mathrm{pH} 7$ for both $\mathrm{CH}$ and collagen resulting in a $\lambda_{\max }$ at $205 \mathrm{~nm}$. The shift demonstrated the tendencies for both $\mathrm{CH}$ and collagen to fold into higher- 
order structures. Collagen is known to arrange into a fibrillar assembly at physiological $\mathrm{pH}$, explaining its blue shift [37]. It was possible that the peptides in $\mathrm{CH}$ oriented themselves to form a sort of quasi-fibrillar structure, mimicking the fibrillar structure of collagen. As the $\mathrm{pH}$ was made more alkaline, the $207 \mathrm{~nm}$ peak of collagen red-shifted to $212 \mathrm{~nm}$ indicating that the supra assembly of collagen misfolded with a tendency to forfeit its fibrillogenic structure. However, $\mathrm{CH}$ did not register a shift in its absorbance maxima, leading to the inference that the quasi-fibrillar structure of $\mathrm{CH}$ was retained even at $\mathrm{pH}$ 8. At $\mathrm{pH} 9$ the amine peak redshifted to $221 \mathrm{~nm}$ for both $\mathrm{CH}$ and collagen depicting the loss of fibrillar property. This was due to the $\mathrm{pH}$-induced negative charge gained by collagen leading to destabilization of the fibril.

The wavelength shifts of the amine group proved to be a favourable indicator of the hierarchical state of both $\mathrm{CH}$ and collagen. The results validated that amide N-H groups in both $\mathrm{CH}$ and collagen display a similar $\mathrm{pH}$-induced absorbance shift confirming that peptides in $\mathrm{CH}$ were mimicking the folded hierarchy of the intact collagen. However, two marked differences were noticeable. At $\mathrm{pH} 4, \mathrm{CH}$ existed in a less folded state than collagen, whereas at $\mathrm{pH} 8, \mathrm{CH}$ managed to retain the fibrillar hierarchy even though collagen lost the same. This signifies that the peptides of $\mathrm{CH}$ subsisted in a more dynamic but stable quasi fibrillar state compared to that of its parent molecule, at least, in the alkaline $\mathrm{pH}$ region.

\subsection{Secondary structure determination of $\mathrm{CH}$}

The circular dichroism spectroscopy measures the difference in absorption of right-handed and left-handed circular polarized light by the ensemble of peptide bonds constituting a protein backbone. Since the orientation of the bonds follows the secondary structure of the protein, CD spectroscopy becomes a powerful and accurate tool to determine the 3-D conformation of the protein $[38,39]$. Both $\mathrm{CH}$ and collagen displayed similar profiles as seen in Fig. 2c. At pH 7, CH and collagen exhibited negative peaks at 196-201nm indicating the presence of PP-II helix as the predominant secondary structure. Both samples displayed a negative value at $207 \mathrm{~nm}$ and a shoulder like protrusion at $222 \mathrm{~nm}$. Changes in the $222 \mathrm{~nm}$ wavelength have been reported to be linked with fibrillogenesis [40,41]. It has also been reported that negative signals between 204 and 210nm were a dominant indicator for the selfassembling tendency of a protein [40]. Based on the two parameters it was concluded that at pH 7, both samples exhibited a hierarchical fibrillar assembly. The data corroborated with the 
interpretations of the spectral shift analysis. It could be concluded that the peptides in $\mathrm{CH}$ wound around each other to form a mimic helix, and these mimic helices associateed through weak interactions to form a quasi-fibril.

\subsection{Dimensions and ZP of $\mathrm{CH}$}

The dynamic Light Scattering (DLS) technique is based on the Brownian motion of dispersed particles. In DLS, an incident light beam scattered by a moving suspended particle is detected in a time-dependent fashion. This scattered light gives an estimate of the hydrodynamic radius of the particle [42].

As seen in Fig. 3a, $\mathrm{CH}$ displays a bimodal distribution indicating higher-order structure formation. The smaller distribution observed at $164.56 \pm 42.5 \mathrm{~nm}$ particle size was due to an initial sidewise association of the mimic helices, that further assembled to form larger quasifibrils with average dimensions of $842.2 \pm 229 \mathrm{~nm}$. Collagen is known to display fibrillar properties at physiological $\mathrm{pH}$, a property reflected in the bimodal size distributions of collagen. The smaller distribution was seen at $226.43 \pm 35.6 \mathrm{~nm}$ matched the size of tropocollagen helices, while the second one was observed at $1260 \pm 1029 \mathrm{~nm}$, which accounted for the lateral associations of the tropocollagen units to form fibrillar structures.

Zeta Potential (ZP) is a characterization technique employed to estimate the physical stability of a suspension by assessing the surface charge of molecules. A larger ZP value (positive or negative) is an indicator of better suspension stability [43]. The $\mathrm{CH}$ and collagen displayed $\mathrm{ZP}$ values of $-164 \mathrm{mV}$ and $-54 \mathrm{mV}$ respectively (Fig. 3b), indicating their propensity to remain in suspended form and not form aggregates. Overall, the DLS data complemented the data obtained from the spectral shift and CD studies.

\subsection{Biomimetic growth of HA crystals on $\mathrm{CH}$}

The yield of $\mathrm{HA}$ from $\mathrm{CH}(\mathrm{CH} / \mathrm{HA})$, based on the mean of multiple setups was determined to be $485.06 \pm 10.2 \mathrm{mg}$. The control sample, HA grown on collagen $(\mathrm{C} / \mathrm{HA})$, yielded a lower amount of $468.02 \pm 14.5 \mathrm{mg}$. This was of principal interest as the authors were unable to find any literature higher yield of HA crystals by using hydrolysate instead of protein or synthesized peptide. A thorough literature review also revealed that a lacuna existed 
regarding the comparison of $\mathrm{HA}$ nucleating capabilities of $\mathrm{CH}$ and collagen. Further structural characteristics were carried out to identify whether the $\mathrm{CH}$ could actually nucleate HA or the higher weight was merely due to the deposition of calcium phosphate.

\subsection{Characteristics of $\mathrm{CH} / \mathrm{HA}$ Nanocomposite}

\subsubsection{Photoluminescence profile of $\mathrm{CH} / \mathrm{HA}$}

Proteins, when excited by light with a wavelength ranging from $260 \mathrm{~nm}$ to $600 \mathrm{~nm}$, exhibits fluorescence property [44]. Intrinsic fluorescence of marine collagen type-I is typically dominated by Phe, Tyr, and Trp residues at 282, 303, and 468nm respectively [45]. The luminescence profiles of the test composite, $\mathrm{CH} / \mathrm{HA}$, and the control, $\mathrm{C} / \mathrm{HA}$ are given in Fig. $4 \mathrm{a}$ and $4 \mathrm{~b}$ respectively. Both reflect the spectral signatures of the above-mentioned residues.

Phe and Tyr exhibited peaks at 284-285nm and 304nm respectively. Even though marine collagen has a higher abundance of Tyr, the low intensity observed in the luminescence profiles was due to collisional quenching with Trp residues located in close vicinity [44]. The peaks ranging from $307-393 \mathrm{~nm}$ were attributed to the presence of Tyr aggregates, arising due to their close proximity in a hierarchical assembly [46,47]. The ubiquitous presence of closely spaced residues in both samples hinted at the presence of similar hierarchical fibrillar assemblies. The intense, sharp peak at $423-424 \mathrm{~nm}$ depicted the presence of dityrosine cross bridges in both samples, a result of glutaraldehyde cross linking $[48,49]$. A prominent peak at $468 \mathrm{~nm}$ in both spectra corresponded to the presence of a tryptophan aromatic ring coupled with the imidazole ring of a neighboring histidine [50]. Trp produced its distinct peak at around $490 \mathrm{~nm}$. Multiple low-intensity peaks at $443 \mathrm{~nm}, 456 \mathrm{~nm}$, and $465 \mathrm{~nm}$ in $\mathrm{CH} / \mathrm{HA}$ corresponded to amino acid residue-mineral interactions.

Two distinct conclusions could be drawn from the close similarity of the $\mathrm{CH} / \mathrm{HA}$ and $\mathrm{C} / \mathrm{HA}$ peaks - (i) the peptides in $\mathrm{CH}$ were able to form a quasi-fibril that closely resembled collagen fibers (ii) $\mathrm{CH}$ was equally effective, if not better, at HA nucleation compared to collagen.

\subsubsection{IR Spectral profile of CH/HA}

FTIR assists in structural investigations of specific functional groups by identifying the vibrations and the change in absorbance profile. Majority of these vibrations are localized on 
the amide and keto groups in the peptide bond. Their sensitivity to hydrogen bonding and dipolar interactions works as useful tools to identify changes in protein secondary structure. Fig. 5a and 5b represent the FTIR spectra of $\mathrm{CH} / \mathrm{HA}$ and the control sample, C/HA.

The Amide A bands arise due to the stretching vibration of $\mathrm{O}-\mathrm{H}$ and $\mathrm{N}-\mathrm{H}$ bond in the range of $3430-3900 \mathrm{~cm}^{-1}[51,52]$. CH/HA exhibited a broad Amide A in the range 3409-3462 $\mathrm{cm}^{-1}$ while the C/HA exhibited a sharp high-intensity band at $3413.4 \mathrm{~cm}^{-1}$. The Amide A peak provides substantial idea about the helical content of the substratum. An N-H stretch less than $3400 \mathrm{~cm}^{-1}$ indicates that the peptide bonds are involved in intra-chain hydrogen bonding [53]. However, a shift to wave number greater than $3400 \mathrm{~cm}^{-1}$, as seen for both $\mathrm{CH} / \mathrm{HA}$ and $\mathrm{C} / \mathrm{HA}$ was indicative of the lower abundance of hydrogen bonding, as expected for peptides existing in PP-II conformation. The Amide B peak representing $>\mathrm{CH}_{2}$ symmetric stretch at $2922 \mathrm{~cm}^{-1}$ confirmed the presence of the protein substratum in both $\mathrm{CH} / \mathrm{HA}$ and $\mathrm{C} / \mathrm{HA}$.

The Amide I band (1630-1680 $\mathrm{cm}^{-1}$ ) occurs primarily due to the stretching vibration of the $\mathrm{C}=\mathrm{O}$ group and it acts as a sensitive marker in the determination of the secondary structure of the protein [52]. The distortions of the $\mathrm{C}-\mathrm{N}$ stretching and $\mathrm{N}-\mathrm{H}$ bending vibrations help in identifying the environment of the bond and consequently, the secondary structure of the organic component. The peaks at $1641-1657 \mathrm{~cm}^{-1}$ were prominent in both samples and indicated the presence of PP-II like coils. The band at $1665 \mathrm{~cm}^{-1}$ was related to the hydrogen bonding propensity of hydroxyproline, a common component of collagen. The peak was significantly prominent in $\mathrm{CH} / \mathrm{HA}$ in comparison to $\mathrm{C} / \mathrm{HA}$, owing to greater vibration in the more open quasi-fibrillar structure of the former in comparison to the tight packing of the latter. The presence of a sub-band near $1683 \mathrm{~cm}^{-1}$ signifies the degree of cross-linking, which is enormously imperative for mineralization [54]. The prominent visibility of $1684 \mathrm{~cm}^{-1}$ peak in $\mathrm{CH} / \mathrm{HA}$ acts as evidence that the $\mathrm{CH}$ peptides were cross-linked more than that of collagen chains. A sub-peak at $1632 \mathrm{~cm}^{-1}$ is known to indicate the presence of denatured coils [55]. $\mathrm{CH} / \mathrm{HA}$ did not display this band indicating that the hierarchical structure was still maintained. However, $\mathrm{CH} / \mathrm{HA}$ did show a band at $1638 \mathrm{~cm}^{-1}$, which possibly indicated that it was less hierarchical than intact collagen.

The Amide II band occurs in the $1335-1402 \mathrm{~cm}^{-1}$ and $1541-1558 \mathrm{~cm}^{-1}$ positions. The former indicates the wagging motion of the proline ring $-\left(\mathrm{CH}_{2}\right)$ - and the latter arises due to $\mathrm{C}-\mathrm{N}$ stretching vibrations in combination with $\mathrm{N}-\mathrm{H}$ bending [56]. Interestingly, during mineralization, the $1335 \mathrm{~cm}^{-1}$ band is masked by a more prominent peak at $1383 \mathrm{~cm}^{-1}$, 
occurring exclusively due to the interaction of $\mathrm{Ca}^{2+}$ with that of the carboxyl group of the protein/hydrolysate substratum. A prominent presence of this peak is considered as a prime marker for designating the state of mineralization [57]. The peak is observed in both nanocomposites, but is significantly larger in $\mathrm{CH} / \mathrm{HA}$, indicating a higher number of interactions between carboxyl groups and $\mathrm{Ca}^{2+}$ and consequently, better mineralization by the $\mathrm{CH}$.

The second Amide II band (1541-1558 $\left.\mathrm{cm}^{-1}\right)$ was different for both nanocomposites. $\mathrm{CH} / \mathrm{HA}$ exhibited peaks at $1539 \mathrm{~cm}^{-1}$ and $1547 \mathrm{~cm}^{-1}$ which corresponded to the presence of triple helices whereas $\mathrm{C} / \mathrm{HA}$ exhibited a single band at $1541 \mathrm{~cm}^{-1}$, which indicated the presence of a distorted triple helix [58]. The Amide III peak has a band range of $1250-1350 \mathrm{~cm}^{-1}$ and arises from the peptide bond $\mathrm{N}-\mathrm{H}$ deformation coupled with $\mathrm{N}-\mathrm{C}$ stretching. The band is barely visible at $1272 \mathrm{~cm}^{-1}$ in $\mathrm{CH} / \mathrm{HA}$. A low amide III is indicative of a hierarchical fibrillar arrangement [59].

$\mathrm{CH} / \mathrm{HA}$ and $\mathrm{C} / \mathrm{HA}$ also exhibited typical peaks of phosphate. $\mathrm{CH} / \mathrm{HA}$ displayed a sharp peak at $1033 \mathrm{~cm}^{-1}$, indicating O-P-O $\left(\square_{3}\right)$ bending [60]. It also exhibited a shoulder peak at $1104 \mathrm{~cm}^{-1}$, a confirmatory peak for the presence of asymmetric HA. C/HA displayed a lower wavenumber band at $1029 \mathrm{~cm}^{-1}$ and a shoulder peak at $1086 \mathrm{~cm}^{-1}$. The $961-968 \mathrm{~cm}^{-1}$ band corresponding to $\mathrm{PO}_{4}^{-3}\left(\square_{1}\right)$ and the double band at $562 \mathrm{~cm}^{-1}$ and $605 \mathrm{~cm}^{-1}$ corresponding to $\mathrm{PO}_{4}^{-3}\left(\square_{4}\right)$ were visible in both profiles. Both samples displayed a peak around $470 \mathrm{~cm}^{-1}$ corresponding to $\mathrm{PO}_{4}^{-3}\left(\square_{2}\right)$ stretch [60]. The presence of all four bands gave a strong indication that phosphate has been incorporated in the apatite formation.

The presence of carbonate peaks acts as indicators for determining the type of apatite formation. As seen in the figure, carbonate peaks were noticeable in the range of 1400$1500 \mathrm{~cm}^{-1}$ and $2320-2370 \mathrm{~cm}^{-1}$, designating the formation of type B apatite wherein a small number of phosphate ions are replaced by carbonate ions $[17,61]$. The increased carbonate ions might be from the atmospheric carbon dioxide which gets trapped into the lattice during crystal formation [62].

Earlier, the luminescence profiles confirmed that the $\mathrm{CH}$ existed as a higher-order fibrillar structure within $\mathrm{CH} / \mathrm{HA}$. The FTIR studies not only corroborated that but added further intriguing aspects. The $\mathrm{CH} / \mathrm{HA}$ profile showed that the peptides existed as PP-II helices and 
even though presence of cross links was evident, the quasi-fibril formed by the $\mathrm{CH}$ peptides was somehow more open and dynamic, with a higher number of calcium-carboxyl interactions.

\subsubsection{XRD profile of $\mathrm{CH} / \mathrm{HA}$}

$\mathrm{XRD}$ is a quantitative method to classify a crystal by detecting its characteristic planes of reflection. Fig. 6a depicts the XRD profile of $\mathrm{CH} / \mathrm{HA}$ with sharp intense bands of $\mathrm{HA}$ overlapped with the broad amorphous phase of $\mathrm{CH}$. A similar pattern was depicted by the control sample C/HA, although, with peaks of lower intensity (Fig. 6b).

The presence of high intensity peaks representing the planes $002\left(2 \theta=25.9^{\circ}\right), 210(2 \theta$ $\left.=29.04^{\circ}\right), 211\left(2 \theta=31.8^{\circ}\right), 112\left(2 \theta=32.5^{\circ}\right), 300\left(2 \theta=32.9^{\circ}\right), 202\left(2 \theta=34.02^{\circ}\right), 310\left(2 \theta=39.8^{\circ}\right)$, $311\left(2 \theta=42.1^{\circ}\right), 222\left(2 \theta=46.7^{\circ}\right), 213\left(2 \theta=49.6^{\circ}\right)$ and $004\left(2 \theta=53.1^{\circ}\right)$ coincided with HA planes listed in ICCD database confirming the presence of HA in CH/HA [63-65]. The control C/HA depicted similar planes with lower intensity indicating a lower crystalline state.

A sharp peak at $2 \theta=7^{\circ}$ denotes the equatorial distance between PP-II helices coiled in a triple helical manner [56]. In this study however, both $\mathrm{CH} / \mathrm{HA}$ and $\mathrm{C} / \mathrm{HA}$ displayed a peak at 9.3 and $9.7^{\circ}$ respectively, which corresponded to a $d$ value of $0.93 \pm 0.028 \mathrm{~nm}$. It was evident that the formation of HA mineral phase was linked to an altered packing of the triple helices. The broad peak at $2 \theta=21.57^{\circ}(200)$ corresponds to a $d$ value of $0.41 \mathrm{~nm}$. This peak is generally corroborated with amorphous scattering from multiple triple helices [66]. The peak was significantly diffused in $\mathrm{CH} / \mathrm{HA}$ because the mimic-helical packing of $\mathrm{CH}$ was more dynamic and less sterically hindered than the intact triple helix of collagen. The larger peak at $2 \theta=$ $31.96^{\circ}$ displayed a $d$ value of $0.285 \mathrm{~nm}$ which denoted the helical rise per residue in peptide chains oriented in a helical manner [67]. The peak at $55.7^{\circ}$ represented a length of $0.17 \mathrm{~nm}$, which was attributed to the radius of a single PP-II helix. Similar peaks were observed in C/HA.

To conclude, $\mathrm{CH}$ displays an exquisite hierarchical assembly initiating with peptides oriented in PP-II conformation coiling with other PP-II peptides to form a triple-helical assembly. The smaller intermolecular packing distance along with a decidedly diffused 200 plane confirmed it to be a "mimic-helix" instead of an actual triple helix. These mimic-helices associated sideways to create a large quasi-fibrillar network, which becomes the substratum for HA 
nucleation and propagation. The sharper planes of $\mathrm{CH} / \mathrm{HA}$ provided confirmatory evidence that crystallinity of $\mathrm{CH} / \mathrm{HA}$ was better than collagen, confirming the superiority of $\mathrm{CH}$ quasifibril over collagen fibrils in HA nucleation.

\subsubsection{Size distribution of $\mathrm{CH} / \mathrm{HA}$}

Fig. 6c describes the particle size distribution as measured by DLS. CH/HA displayed an average size of $41.16 \pm 13.21 \mathrm{~nm}$ which was lower than the size distribution of $\mathrm{C} / \mathrm{HA}$; $58.2 \pm 18.7 \mathrm{~nm}$. The difference between the two samples was statistically significant $(\mathrm{p}<0.05$, by t-test) indicating $\mathrm{CH}$ was able to nucleate crystals of smaller dimensions.

The $\mathrm{ZP}$ of $\mathrm{CH} / \mathrm{HA}$ and $\mathrm{C} / \mathrm{HA}$ ranged from +4.8 to $+4.9 \mathrm{mV}$ (Fig. 6d). Biological macromolecules that exhibit $\mathrm{ZP}$ in the range of $-25 \mathrm{mV}$ to $+25 \mathrm{mV}$ are known to aggregate quickly in physiological fluids [43,68]. The composites exhibited low ZP indicating their low propensity to disassociate from a coating.

\subsubsection{SEM-EDX profile of $\mathrm{CH} / \mathrm{HA}$}

The morphology of the CH/HA and C/HA nanocomposites are shown in Fig. 7a and 7b. The crystals exhibited a plate-like arrangement with serrated edges representing growing crystal planes $[69,70]$. Both nanocomposites depict a variety of size ranges. The $\mathrm{CH} / \mathrm{HA}$ crystals recorded a small size range of 50-380nm while the C/HA crystals were larger (180-450nm). HA crystals with smaller dimensions effectively influence their biological and mechanical responses when used as coating materials [71,72]. This is one of the attractive features for the utilization of $\mathrm{CH} / \mathrm{HA}$ as a coating material in comparison to $\mathrm{C} / \mathrm{HA}$.

$\mathrm{Ca}$ and $\mathrm{P}$ exist in multiple phases such as amorphous calcium phosphates, brushite, monetite, tricalcium phosphate and hydroxyapatite. However, biomimetic synthesis ensures that the crystalline phase formed comprises majorly hydroxyapatite. The phases can be distinguished by the $\mathrm{Ca} / \mathrm{P}$ ratio. Brushite and monetite exhibit a $\mathrm{Ca} / \mathrm{P}$ ratio in the range of 1.1 to 1.3 , whereas TCP and HA display a $\mathrm{Ca} / \mathrm{P}$ ratio of 1.5 and 1.69 respectively [73]. The SEM-EDX data (Fig. 7c) reveals that the $\mathrm{Ca} / \mathrm{P}$ ratio of $\mathrm{CH} / \mathrm{HA}$ and $\mathrm{C} / \mathrm{HA}$ nanocomposites in this study was 1.78 and 1.95 respectively. The $\mathrm{Ca} / \mathrm{P}$ ratio of $\mathrm{CH} / \mathrm{HA}$ is in close accordance with the 1.67 value for pure HA [74]. The $\mathrm{Ca} / \mathrm{P}$ value of 1.78 for $\mathrm{CH} / \mathrm{HA}$ matched with values obtained through previous biomimetic studies $[17,75]$. The observation of a small amount of $\mathrm{Na}$ in EDX results is in accordance with the published studies [76]. 


\subsubsection{Dimensional analysis of $\mathrm{CH} / \mathrm{HA}$}

Accurate dimensions for the CH/HA crystals were obtained through AFM. As seen from Fig. $7 \mathrm{~d}$, the nanometric crystals exhibited an irregular oval shape with even smaller crystals scattered on the surface. The CH/HA crystals exhibited a size of $48 \pm 6.2 \mathrm{~nm}$, which matched the data obtained from DLS and SEM. Smaller particle sizes of constituent coating material enhance the surface roughness in the nanoscale. This property is important as pathogenrelated contamination occurs less on nanosurfaces, giving the coating a distinctive advantage. As the surface roughness reduces from the sub-micron scale to the nano-scale level, two phenomena occur - the surface state gradually changes from hydrophobic to hydrophilic and becomes increasingly unfavorable for the adhesion of most bacteria. Second, the anchoring points for bacterial adhesion gradually decrease, weakening the bacterial-surface bonding strength [77,78]. At the same time, the nanometric roughness ensures integrin activation leading to higher osteoblast attachment [79]. Based on the size, it was expected that the $\mathrm{CH} / \mathrm{HA}$ would work as a better osteoblast adhesion/ proliferation agent.

\subsection{Osteoblast adhesion/ proliferation studies on $\mathrm{CH} / \mathrm{HA}$}

The physicochemical properties of an implant surface, including hydrophobicity, surface free energy and roughness are an absolute necessity for selective osteoblast adhesion [77]. As seen in Fig. 8a, the amount coated had a significant effect $(\mathrm{p}<0.01)$ on the number of cells adhered. Overall, the adhesion exhibited a bell-shaped profile with maximum adhesion occurring around the $100-250 \mu \mathrm{g}$ range. This was expected from collagen-coated wells as excess collagen often eclipses the cell adhesion sites, reducing the number of cells that can adhere [80]. The nanocomposites followed a similar pattern. The cells adhered much better on the nanocomposites when compared to that of collagen-coated dishes, indicating the "osteophilicity" of the coat. A comparison between the adhesion capacity of $\mathrm{CH} / \mathrm{HA}$ and $\mathrm{C} / \mathrm{HA}$ displayed that overall, the former adheres to a higher number of cells. At $250 \mu \mathrm{g}$ $\mathrm{CH} / \mathrm{HA}$, the adhered cell count was significantly higher $(\mathrm{p}<0.05)$ than that of $\mathrm{C} / \mathrm{HA}$.

Fig. $8 \mathrm{~b}$ depicts the effect of nanocomposites on the rate of cell proliferation. Cells grown on nanocomposites and collagen displayed a normal growth rate after $20 \mathrm{~h}$. However, cells in the uncoated wells initiated a growth phase only after $36 \mathrm{~h}$. Cells proliferated significantly faster $(\mathrm{p}<0.01)$ on $\mathrm{C} / \mathrm{HA}$ and $\mathrm{CH} / \mathrm{HA}$ when compared to collagen-coated wells. Among the nanocomposites, cells growing on $\mathrm{CH} / \mathrm{HA}$ were significantly higher $(\mathrm{p}<0.05)$ than $\mathrm{C} / \mathrm{HA}$. As 
seen in the figure, cells on $\mathrm{CH} / \mathrm{HA}$ displayed exponential growth phase even at $72 \mathrm{~h}$. The proliferation rate on $\mathrm{CH} / \mathrm{HA}$ was faster than $\mathrm{C} / \mathrm{HA}$ by a factor of 1.39 and from coated dishes by a factor of 1.83. The doubling time of the cells on $\mathrm{CH} / \mathrm{HA}$ and $\mathrm{C} / \mathrm{HA}$ were 21.4 and 24.9 hours respectively while it took $28 \mathrm{~h}$ for doubling on only collagen-coated wells. Fig. $8 \mathrm{c}$ provides the photomicrograph of cells grown till 60h with maximum cells observed on the $\mathrm{CH} / \mathrm{HA}$ coated surface. Fig. 8d provides an illustration of the cell adhesion and proliferation occurring on three different coating surfaces. The osteoblast study corroborated previous reports that nanometric HA surfaces support higher osteoblast cell density [71,72] and provided evidence that $\mathrm{HA}$ grown on $\mathrm{CH}$ was a better osteophilic material than $\mathrm{C} / \mathrm{HA}$.

\section{Conclusion}

The study provided evidence that under in vitro conditions, collagen hydrolysate was able to nucleate nanophasic HA without the aid of any other externally added protein including collagen. The nanophasic $\mathrm{CH} / \mathrm{HA}$ crystals exhibited higher yield and smaller dimensions when compared to the standard collagen-based nanocomposites and when used as a coating, was significantly better at osteoblast adhesion and proliferation.

The main reason for the high $\mathrm{HA}$ nucleation ability of $\mathrm{CH}$ was due to its intriguing quasifibrillar nature. The prevalence of proline constrained the peptides to orient in a PP-II conformation and coil with each other to form a triple-helical assembly. Owing to the smaller size (about $6 \mathrm{kDa}$ ), the triple-helical peptide fabrication was of diminished proportions with a reduced equatorial packing distance when compared to the collagen triple helix, and hence was coined as a "mimic-helix". These mimic helices associated through hydrogen bonding to form a large quasi-fibrillar network that was more stable than collagen over the $\mathrm{pH}$ range of 6-8. At the same time, the $\mathrm{CH}$ fibrils were smaller in dimensions and more widespread in size, indicating their dynamic nature.

Structural studies on the nanocomposite of CH/HA revealed that the mimic-helix/ quasifibrillar hierarchy was maintained even after the hydrolysate was mineralized. The dynamic aspect of the $\mathrm{CH}$ quasi-fibril combined with a large number of $\mathrm{C}$-terminals led to a massive number of exposed carboxylate groups that acted as calcium anchorage points more effectively than collagen, as evidenced by the presence of a distinctly prominent peak at $1383 \mathrm{~cm}^{-1}$. At the same time, the high stability of quasi-fibrils assured that the groups maintained the orientation for a longer duration allowing crystallization to proceed. The 
addition of a minimum quantity of glutaraldehyde to the fibrils led to a large number of crosslinks, as evidenced in the PLA and FTIR profiles, consequently contributing to the stability of the system.

A significant number of supportive markers demarcated the efficacy of the CH-based HA nucleation, the foremost of which was the higher yield when compared to collagen-based nucleation. The sharper HA-specific planes in $\mathrm{CH} / \mathrm{HA}$ established the higher crystalline nature of $\mathrm{CH} / \mathrm{HA}$ over that of $\mathrm{C} / \mathrm{HA}$. This was complemented by SEM and AFM results which yielded nanometric $\mathrm{CH} / \mathrm{HA}$ crystals with smaller dimensions - an absolute necessity for osteoblast adhesion. The $\mathrm{Ca} / \mathrm{P}$ ratio of $\mathrm{CH} / \mathrm{HA}$ exhibited a value of 1.78 which was close to previous biomimetic HA and the value of pure HA (1.69). And to sum it all, the $\mathrm{CH} / \mathrm{HA}$ nanocomposite was significantly better than collagen/HA in osteoblast adhesion and proliferation.

The present study furnishes the fact that the peptide-based dynamic quasi-fibril can act as better nucleating agents than the parent protein. This stand-alone property of $\mathrm{CH}$ demonstrates the absolute significance of protein secondary structure in biomineralization and provides an intriguing and eloquent insight into the biochemistry of collagen hydrolysate. Simultaneously, the results of this study provide substantial evidence for the "structural" theory, indicating that in vivo, the hierarchical assembly of an organic substratum, be it intact or hydrolzed, can both initiate and propagate the nucleation. The detailed morphological and analytical studies of nanocomposite act as a step forward in deciphering the qualitative and quantitative magnitude of this uniquely conserved protein in the field of biomimetics. The data acquired can act as a tie-in study to pursue the effectiveness of $\mathrm{CH}$-based coatings on implants as an alternative to collagen-based coatings as a faster osseointegrative material.

\section{Acknowledgment}

Some of the components of the illustrations in the graphical abstract and Fig. 8d have been taken from Servier Medical Smartarts. The authors thank the Chemistry Department of Dayananda Sagar University for their help in obtaining the FTIR profiles. The authors are grateful to Ms Prakruti Acharya for the immense help provided.

\section{Funding}

This work was funded by the Science and Engineering Research Board, Department of Science and Technology, Govt. of India (Grant No: SERB/ECR/2016/001526). The authors 
also acknowledge their gratitude towards the Centre of Innovative Science and Engineering at the Dayananda Sagar Institution, sponsored by the Govt. of Karnataka, for equipment utilization.

\section{Conflict of Interest: None}

\section{References}

[1] Jin, W., Chu, P.K., 2019. Orthopedic Implants, in: Narayan, R. (Ed.), Encyclopedia of Biomedical Engineering. Elsevier, Oxford, pp. 425-439. https://doi.org/10.1016/B978-012-801238-3.10999-7

[2] Arcos, D., Vallet-Regí, M., 2020. Substituted hydroxyapatite coatings of bone implants. J. Mater. Chem. B 8, 1781-1800. https://doi.org/10.1039/C9TB02710F

[3] Ma, T., Goodman, S.B., 2011. 6.606 - Biological Effects of Wear Debris from Joint Arthroplasties, in: Ducheyne, P. (Ed.), Comprehensive Biomaterials. Elsevier, Oxford, pp. 79-87. https://doi.org/10.1016/B978-0-08-055294-1.00204-X

[4] Kose, N., Ayse Kose, A., 2015. Chapter 7 - Application of Nanomaterials in Prevention of Bone and Joint Infections, in: Rai, M., Kon, K. (Eds.), Nanotechnology in Diagnosis, Treatment and Prophylaxis of Infectious Diseases. Academic Press, Boston, pp. 107-117. https://doi.org/10.1016/B978-0-12-801317-5.00007-4

[5] Rivera-Muñoz, E.M., 2011. Hydroxyapatite-Based Materials: Synthesis and Characterization. Biomedical Engineering - Frontiers and Challenges. https://doi.org/10.5772/19123

[6] Ma, G., 2019. Three common preparation methods of hydroxyapatite. IOP Conf. Ser.: Mater. Sci. Eng. 688, 033057. https://doi.org/10.1088/1757-899X/688/3/033057

[7] Wei, G., Gong, C., Hu, K., Wang, Y., Zhang, Y., 2019. Biomimetic Hydroxyapatite on Graphene Supports for Biomedical Applications: A Review. Nanomaterials 9, 1435. https://doi.org/10.3390/nano9101435

[8] Combes, C., Cazalbou, S., Rey, C., 2016. Apatite Biominerals. Minerals 6, 34. https://doi.org/10.3390/min6020034

[9] Sailaja, G.S., Ramesh, P., Vellappally, S., Anil, S., Varma, H.K., 2016. Biomimetic approaches with smart interfaces for bone regeneration. Journal of Biomedical Science 23, 77. https://doi.org/10.1186/s12929-016-0284-x

[10] Quan, B.D., Sone, E.D., 2018. The effect of polyaspartate chain length on mediating biomimetic remineralization of collagenous tissues. Journal of The Royal Society Interface 15, 20180269. https://doi.org/10.1098/rsif.2018.0269

[11] Tan, X., Xue, Z., Zhu, H., Wang, X., Xu, D., 2020. How Charged Amino Acids Regulate Nucleation of Biomimetic Hydroxyapatite Nanoparticles on the Surface of Collagen Mimetic Peptides: Molecular Dynamics and Free Energy Investigations. Crystal Growth \& Design 20, 4561-4572. https://doi.org/10.1021/acs.cgd.0c00353

[12] Jiang, S., Cao, Y., Li, S., Pang, Y., Sun, Z., 2021. Dual function of poly(acrylic acid) on controlling amorphous mediated hydroxyapatite crystallization. Journal of Crystal Growth 557, 125991. https://doi.org/10.1016/j.jcrysgro.2020.125991 
[13] Wang, Y., Azaïs, T., Robin, M., Vallée, A., Catania, C., Legriel, P., Pehau-Arnaudet, G., Babonneau, F., Giraud-Guille, M.-M., Nassif, N., 2012. The predominant role of collagen in the nucleation, growth, structure and orientation of bone apatite. Nat Mater 11, 724-733. https://doi.org/10.1038/nmat3362

[14] Nudelman, F., Pieterse, K., George, A., Bomans, P.H.H., Friedrich, H., Brylka, L.J., Hilbers, P.A.J., de With, G., Sommerdijk, N.A.J.M., 2010. The role of collagen in bone apatite formation in the presence of hydroxyapatite nucleation inhibitors. Nature Materials 9, 1004-1009. https://doi.org/10.1038/nmat2875

[15] Chen, Y., Feng, Y., Deveaux, J.G., Masoud, M.A., Chandra, F.S., Chen, H., Zhang, D., Feng, L., 2019. Biomineralization Forming Process and Bio-inspired Nanomaterials for Biomedical Application: A Review. Minerals 9, 68. https://doi.org/10.3390/min9020068

[16] Rivas, M., del Valle, L.J., Alemán, C., Puiggalí, J., 2019. Peptide Self-Assembly into Hydrogels for Biomedical Applications Related to Hydroxyapatite. Gels 5, 14. https://doi.org/10.3390/gels5010014

[17] Banerjee, P., Madhu, S., Chandra Babu, N.K., Shanthi, C., 2015. Bio-mimetic mineralization potential of collagen hydrolysate obtained from chromium tanned leather waste. Materials Science and Engineering: C 49, 338-347.

https://doi.org/10.1016/j.msec.2015.01.027

[18] Ficai, A., Albu, M.G., Birsan, M., Sonmez, M., Ficai, D., Trandafir, V., Andronescu, E., 2013. Collagen hydrolysate based collagen/hydroxyapatite composite materials. Journal of Molecular Structure 1037, 154-159. https://doi.org/10.1016/j.molstruc.2012.12.052

[19] The State of World Fisheries and Aquaculture 2020, 2020. . FAO. https://doi.org/10.4060/ca9229en

[20] Bais, B., 2018. Fish scenario in India with emphasis on Indian major carps. IJAWB 3. https://doi.org/10.15406/ijawb.2018.03.00130

[21] Das, J., Dey, P., Chakraborty, T., Saleem, K., Nagendra, R., Banerjee, P., 2018. Utilization of marine industry waste derived collagen hydrolysate as peroxide inhibition agents in lipid-based food. Journal of Food Processing and Preservation 42, 1-11. https://doi.org/10.1111/jfpp.13430

[22] Laemmli, U.K., 1970. Cleavage of structural proteins during the assembly of the head of bacteriophage T4. Nature 227, 680-685. https://doi.org/10.1038/227680a0

[23] Wong, C., Sridhara, S., Bardwell, J., Jakob, U., 2000. Heating Greatly Speeds Coomassie Blue Staining and Destaining. BioTechniques 28, 426-8, 430, 432. https://doi.org/10.2144/00283bm07

[24] Pal, G.K., Nidheesh, T., Suresh, P.V., 2015. Comparative study on characteristics and in vitro fibril formation ability of acid and pepsin soluble collagen from the skin of catla ( Catla catla ) and rohu ( Labeo rohita ). Food Research International 76, 804-812. https://doi.org/10.1016/j.foodres.2015.07.018

[25] Bhuimbar, M.V., Bhagwat, P.K., Dandge, P.B., 2019. Extraction and characterization of acid soluble collagen from fish waste: Development of collagen-chitosan blend as food packaging film. Journal of Environmental Chemical Engineering 7, 102983.

https://doi.org/10.1016/j.jece.2019.102983

[26] Blanco, M., Vázquez, J.A., Pérez-Martín, R.I., Sotelo, C.G., 2017. Hydrolysates of Fish Skin Collagen: An Opportunity for Valorizing Fish Industry Byproducts. Marine Drugs 15, 131. https://doi.org/10.3390/md15050131 
[27] Abdollahi, M., Rezaei, M., Jafarpour, A., Undeland, I., 2018. Sequential extraction of gel-forming proteins, collagen and collagen hydrolysate from gutted silver carp (Hypophthalmichthys molitrix), a biorefinery approach. Food Chemistry 242, 568-578. https://doi.org/10.1016/j.foodchem.2017.09.045

[28] Duan, R., Zhang, J., Du, X., Yao, X., Konno, K., 2009. Properties of collagen from skin, scale and bone of carp (Cyprinus carpio). Food Chemistry 112, 702-706. https://doi.org/10.1016/j.foodchem.2008.06.020

[29] Ali, A.M.M., Kishimura, H., Benjakul, S., 2018. Extraction efficiency and characteristics of acid and pepsin soluble collagens from the skin of golden carp (Probarbus Jullieni) as affected by ultrasonication. Process Biochemistry 66, 237-244. https://doi.org/10.1016/j.procbio.2018.01.003

[30] Pal, G.K., Nidheesh, T., Suresh, P.V., 2015. Comparative study on characteristics and in vitro fibril formation ability of acid and pepsin soluble collagen from the skin of catla (Catla catla) and rohu (Labeo rohita). Food Research International 76, 804-812. https://doi.org/10.1016/j.foodres.2015.07.018

[31] Muralidharan, N., Jeya Shakila, R., Sukumar, D., Jeyasekaran, G., 2013. Skin, bone and muscle collagen extraction from the trash fish, leather jacket (Odonus niger) and their characterization. J Food Sci Technol 50, 1106-1113. https://doi.org/10.1007/s13197-0110440-y

[32] Coelho, R.C.G., Marques, A.L.P., Oliveira, S.M., Diogo, G.S., Pirraco, R.P., MoreiraSilva, J., Xavier, J.C., Reis, R.L., Silva, T.H., Mano, J.F., 2017. Extraction and characterization of collagen from Antarctic and Sub-Antarctic squid and its potential application in hybrid scaffolds for tissue engineering. Materials Science and Engineering: C 78, 787-795. https://doi.org/10.1016/j.msec.2017.04.122

[33] Zhang, Y.-Z., Ran, L.-Y., Li, C.-Y., Chen, X.-L., 2015. Diversity, Structures, and Collagen-Degrading Mechanisms of Bacterial Collagenolytic Proteases. Appl. Environ. Microbiol. 81, 6098-6107. https://doi.org/10.1128/AEM.00883-15

[34] Paola, C.M., Camila, A.M., Ana, C., Marlon, O., Diego, S., Robin, Z., Beatriz, G., Cristina, C., 2019. Functional textile finishing of type I collagen isolated from bovine bone for potential healthtech. Heliyon 5, e01260. https://doi.org/10.1016/j.heliyon.2019.e01260

[35] Savedboworn, W., Kittiphattanabawon, P., Benjakul, S., Sinthusamran, S., Kishimura, H., 2017. Characteristics of Collagen from Rohu (Labeo rohita) Skin. Journal of Aquatic Food Product Technology 26, 248-257. https://doi.org/10.1080/10498850.2015.1133747

[36] Saraiva, M.A., 2020. Interpretation of $\alpha$-synuclein UV absorption spectra in the peptide bond and the aromatic regions. Journal of Photochemistry and Photobiology B:

Biology 212, 112022. https://doi.org/10.1016/j.jphotobiol.2020.112022

[37] Harris, J.R., Reiber, A., 2007. Influence of saline and $\mathrm{pH}$ on collagen type I fibrillogenesis in vitro: Fibril polymorphism and colloidal gold labelling. Micron 38, $513-$ 521. https://doi.org/10.1016/j.micron.2006.07.026

[38] Towell, J.F., Manning, M.C., 1994. Chapter 6 Analysis of protein structure by circular dichroism spectroscopy, in: Techniques and Instrumentation in Analytical Chemistry.

Elsevier, pp. 175-205. https://doi.org/10.1016/S0167-9244(08)70179-3

[39] Sarem, M., Lüdeke, S., 2015. Circular dichroism: A powerful tool for studying biomineralization promoter proteins. MRS Bull. 40, 490-498.

https://doi.org/10.1557/mrs.2015.116 
[40] Drzewiecki, K.E., Grisham, D.R., Parmar, A.S., Nanda, V., Shreiber, D.I., 2016. Circular Dichroism Spectroscopy of Collagen Fibrillogenesis: A New Use for an Old Technique. Biophysical Journal 111, 2377-2386. https://doi.org/10.1016/j.bpj.2016.10.023

[41] Cui, S.-J., Fu, Y., Liu, Y., Kou, X.-X., Zhang, J.-N., Gan, Y.-H., Zhou, Y.-H., Wang, X.-D., 2019. Chronic inflammation deteriorates structure and function of collagen fibril in rat temporomandibular joint disc. International Journal of Oral Science 11, 1-8. https://doi.org/10.1038/s41368-018-0036-8

[42] Stetefeld, J., McKenna, S.A., Patel, T.R., 2016. Dynamic light scattering: a practical guide and applications in biomedical sciences. Biophysical Review 8, 409-427.

https://doi.org/10.1007/s12551-016-0218-6

[43] Joseph, E., Singhvi, G., 2019. Chapter 4 - Multifunctional nanocrystals for cancer therapy: a potential nanocarrier, in: Grumezescu, A.M. (Ed.), Nanomaterials for Drug Delivery and Therapy. William Andrew Publishing, pp. 91-116. https://doi.org/10.1016/B978-0-12-816505-8.00007-2

[44] Lakowicz, J.R., Masters, B.R., 2008. Principles of Fluorescence Spectroscopy, Third Edition. J. Biomed. Opt. 13, 029901. https://doi.org/10.1117/1.2904580

[45] Shen, Y., Zhu, D., Lu, W., Liu, B., Li, Y., Cao, S., 2018. The Characteristics of Intrinsic Fluorescence of Type I Collagen Influenced by Collagenase I. Applied Sciences 8, 1947. https://doi.org/10.3390/app8101947

[46] Li, J., Liu, W., Li, G., 2015. The effect of glycerol and 2-propanol on the molecular aggregation of collagen in solution. International Journal of Biological Macromolecules 72, 1097-1103. https://doi.org/10.1016/j.ijbiomac.2014.10.032

[47] Duan, L., Yuan, J., Yang, X., Cheng, X., Li, J., 2016. Interaction study of collagen and sericin in blending solution. International Journal of Biological Macromolecules 93, 468-475. https://doi.org/10.1016/j.ijbiomac.2016.09.003

[48] Nagaraj, S., Easwaramoorthi, S., Rao, J.R., Thanikaivelan, P., 2019. Probing visible light induced photochemical stabilization of collagen in green solvent medium.

International Journal of Biological Macromolecules 131, 779-786.

https://doi.org/10.1016/j.ijbiomac.2019.03.109

[49] Yova, D.M., Hovhannisyan, V.A., Theodossiou, T., 2001. Photochemical effects and hypericin photosensitized processes in collagen. Journal of Biomedical Optics 6, 52-57. https://doi.org/10.1117/1.1331559

[50] Stepanenko, O., Verkhusha, V., Kuznetsova, I., Uversky, V., Turoverov, K., 2008. Fluorescent Proteins as Biomarkers and Biosensors: Throwing Color Lights on Molecular and Cellular Processes. Current Protein and Peptide Science 9, 338-369. https://doi.org/10.2174/138920308785132668

[51] Durdu, S., Deniz, Ö.F., Kutbay, I., Usta, M., 2013. Characterization and formation of hydroxyapatite on Ti6A14V coated by plasma electrolytic oxidation. Journal of Alloys and Compounds 551, 422-429. https://doi.org/10.1016/j.jallcom.2012.11.024

[52] Tamilmozhi, S., Veeruraj, A., Arumugam, M., 2013. Isolation and characterization of acid and pepsin-solubilized collagen from the skin of sailfish (Istiophorus platypterus). Food Research International 54, 1499-1505. https://doi.org/10.1016/j.foodres.2013.10.002 
[53] McQuade, D.T., McKay, S.L., Powell, D.R., Gellman, S.H., 1997. Indifference to Hydrogen Bonding in a Family of Secondary Amides. Journal of American Chemical Society 119, 8528-8532. https://doi.org/10.1021/ja9711019

[54] Chang, M.C., Tanaka, J., 2002. FT-IR study for hydroxyapatite/collagen nanocomposite cross-linked by glutaraldehyde. Biomaterials 23, 4811-4818. https://doi.org/10.1016/s0142-9612(02)00232-6

[55] de Campos Vidal, B., Mello, M.L.S., 2011. Collagen type I amide I band infrared spectroscopy. Micron 42, 283-289. https://doi.org/10.1016/j.micron.2010.09.010

[56] El-Rashidy, A.A., Gad, A., Abu-Hussein, A.E.-H.G., Habib, S.I., Badr, N.A., Hashem, A.A., 2015. Chemical and biological evaluation of Egyptian Nile Tilapia (Oreochromis niloticas) fish scale collagen. International Journal of Biological Macromolecules 79, 618-626. https://doi.org/10.1016/j.ijbiomac.2015.05.019

[57] Li, J., Zhu, D., Yin, J., Liu, Y., Yao, F., Yao, K., 2010. Formation of nanohydroxyapatite crystal in situ in chitosan-pectin polyelectrolyte complex network. Materials Science and Engineering: C 30, 795-803.

https://doi.org/10.1016/j.msec.2010.03.011

[58] Riaz, T., Zeeshan, R., Zarif, F., Ilyas, K., Muhammad, N., Safi, S.Z., Rahim, A., Rizvi, S.A.A., Rehman, I.U., 2018. FTIR analysis of natural and synthetic collagen.

Applied Spectroscopy Reviews 53, 703-746. https://doi.org/10.1080/05704928.2018.1426595

[59] Qi, P., Zhou, Y., Wang, D., He, Z., Li, Z., 2015. A new collagen solution with high concentration and collagen native structure perfectly preserved. RSC Adv. 5, 87180 87186. https://doi.org/10.1039/C5RA14423J

[60] Lopes, C. de C.A., Limirio, P.H.J.O., Novais, V.R., Dechichi, P., 2018. Fourier transform infrared spectroscopy (FTIR) application chemical characterization of enamel, dentin and bone. Applied Spectroscopy Reviews 53, 747-769.

https://doi.org/10.1080/05704928.2018.1431923

[61] Antonakos, A., Liarokapis, E., Leventouri, T., 2007. Micro-Raman and FTIR studies of synthetic and natural apatites. Biomaterials 28, 3043-3054.

https://doi.org/10.1016/j.biomaterials.2007.02.028

[62] Balakrishnan, S., Ananthasivan, K., Hari Kumar, K.C., 2014. Studies on the synthesis and sintering of nanocrystalline yttria. Ceramics International 40, 6777-6785.

https://doi.org/10.1016/j.ceramint.2013.12.001

[63] Venkateswarlu, D., D, S., M, S., Muthupandi, V., Bose, A., Rameshbabu, N., 2012. X-Ray Peak Profile Analysis of Nanostructured Hydroxyapatite and Fluorapatite. International Journal of Bioscience, Biochemistry and Bioinformatics 2. https://doi.org/10.7763/IJBBB.2012.V2.139

[64] Brundavanam, R.K., Poinern, G.E.J., Fawcett, D., 2013. Modelling the Crystal Structure of a $30 \mathrm{~nm}$ Sized Particle based Hydroxyapatite Powder Synthesised under the Influence of Ultrasound Irradiation from X-ray powder Diffraction Data. American Journal of Materials Science 3, 84-90.

[65] Niu, X., Fan, R., Guo, X., Du, T., Yang, Z., Feng, Q., Fan, Y., 2017. Shear-mediated orientational mineralization of bone apatite on collagen fibrils. Journal of Material Chemistry B 5, 9141-9147. https://doi.org/10.1039/C7TB02223A 
[66] Zhang, F., Wang, A., Li, Z., He, S., Shao, L., 2011. Preparation and Characterisation of Collagen from Freshwater Fish Scales. Food and Nutrition Sciences 2, 818-823.

https://doi.org/10.4236/fns.2011.28112

[67] Terzi, A., Storelli, E., Bettini, S., Sibillano, T., Altamura, D., Salvatore, L., Madaghiele, M., Romano, A., Siliqi, D., Ladisa, M., De Caro, L., Quattrini, A., Valli, L., Sannino, A., Giannini, C., 2018. Effects of processing on structural, mechanical and biological properties of collagen-based substrates for regenerative medicine. Scientific Reports 8, 1429. https://doi.org/10.1038/s41598-018-19786-0

[68] Zaman, M., Ahmad, E., Qadeer, A., Rabbani, G., Khan, R.H., 2014. Nanoparticles in relation to peptide and protein aggregation. International Journal of Nanomedicine 9, 899912. https://doi.org/10.2147/IJN.S54171

[69] Chen, J., Wang, Y., Chen, X., Ren, L., Lai, C., He, W., Zhang, Q., 2011. A simple sol-gel technique for synthesis of nanostructured hydroxyapatite, tricalcium phosphate and biphasic powders. Materials Letters 65, 1923-1926.

https://doi.org/10.1016/j.matlet.2011.03.076

[70] Panggabean, R.D., Yusuf, Y., 2018. Preparation and Characterization of Hydroxyapatite Based on Human teeth with Various of Calcination, in: 2018 1st International Conference on Bioinformatics, Biotechnology, and Biomedical Engineering Bioinformatics and Biomedical Engineering. Presented at the 2018 1st International Conference on Bioinformatics, Biotechnology, and Biomedical Engineering (BioMIC), IEEE, Yogyakarta, pp. 1-4. https://doi.org/10.1109/BIOMIC.2018.8610554

[71] Rios-Pimentel, F.F., Chang, R., Webster, T.J., Méndez-González, M.M., GarcíaRocha, M., 2019. Greater osteoblast densities due to the addition of amphiphilic peptide nanoparticles to nano hydroxyapatite coatings. International Journal of Nanomedicine Volume 14, 3265-3272. https://doi.org/10.2147/IJN.S189323

[72] Jiang, P., Zhang, Y., Hu, R., Wang, X., Lai, Y., Rui, G., Lin, C., 2021.

Hydroxyapatite-modified micro/nanostructured titania surfaces with different crystalline phases for osteoblast regulation. Bioactive Materials 6, 1118-1129. https://doi.org/10.1016/j.bioactmat.2020.10.006

[73] Gomes, D.S., Santos, A.M.C., Neves, G.A., Menezes, R.R., 2019. A brief review on hydroxyapatite production and use in biomedicine. Cerâmica 65, 282-302. https://doi.org/10.1590/0366-69132019653742706

[74] Senra, M.R., Lima, R.B. de, Souza, D. de H.S., Marques, M. de F.V., Monteiro, S.N., 2020. Thermal characterization of hydroxyapatite or carbonated hydroxyapatite hybrid composites with distinguished collagens for bone graft. Journal of Materials Research and Technology 9, 7190-7200. https://doi.org/10.1016/j.jmrt.2020.04.089

[75] Banerjee, P., Das, J., Tripathi, S., 2018. Biomimetic synthesis of nanocrystalline hydroxyapatite from sharkskin collagen. Bioinspired, Biomimetic and Nanobiomaterials 7 , 27-36. https://doi.org/10.1680/jbibn.16.00018

[76] Salama, A., El-Sakhawy, M., 2016. Regenerated cellulose/wool blend enhanced biomimetic hydroxyapatite mineralization. International Journal of Biological Macromolecules 92, 920-925. https://doi.org/10.1016/j.ijbiomac.2016.07.077

[77] Camargo, S.E.A., Roy, T., Carey IV, P.H., Fares, C., Ren, F., Clark, A.E., EsquivelUpshaw, J.F., 2020. Novel Coatings to Minimize Bacterial Adhesion and Promote 
Osteoblast Activity for Titanium Implants. JFB 11, 42.

https://doi.org/10.3390/jfb11020042

[78] Lu, A., Gao, Y., Jin, T., Luo, X., Zeng, Q., Shang, Z., 2020. Effects of surface

roughness and texture on the bacterial adhesion on the bearing surface of bio-ceramic joint implants: An in vitro study. Ceramics International 46, 6550-6559.

https://doi.org/10.1016/j.ceramint.2019.11.139

[79] Zhu, L., Luo, D., Liu, Y., 2020. Effect of the nano/microscale structure of biomaterial scaffolds on bone regeneration. International Journal of Oral Science 12, 1-15.

https://doi.org/10.1038/s41368-020-0073-y

[80] Banerjee, P., Mehta, A., Shanthi, C., 2014. Screening for novel cell adhesive regions in bovine Achilles tendon collagen peptides. Biochemistry and Cell Biology 92, 9-22.

https://doi.org/10.1139/bcb-2013-0026 
Table 1 - Isolation of Collagen type 1 from Pacu skin. The dry weights in grams were noted as $\mathrm{W} 1, \mathrm{~W} 2, \mathrm{~W} 3$ and $\mathrm{W} 4$ for skin, after cleaning, $\mathrm{NaOH}$, Butanol and alkaline EDTA treatment respectively. W5g accounts for insoluble material after acetic acid treatment while W6g represents soluble collagen.

\begin{tabular}{|c|c|c|c|c|c|c|c|c|c|c|c|}
\hline Sample & $\begin{array}{l}\text { W1 } \\
(\mathrm{g})\end{array}$ & Iי & $\begin{array}{l}\text { W2 } \\
(\mathrm{g})\end{array}$ & $\begin{array}{l}\vec{O} \\
\stackrel{\Xi}{\sigma}\end{array}$ & $\begin{array}{l}\text { W3 } \\
\text { (g) }\end{array}$ & $\overleftrightarrow{E}$ & $\begin{array}{l}\text { W4 } \\
(\mathrm{g})\end{array}$ & 恶 & $\begin{array}{l}\text { Insoluble } \\
\text { W5 (g) }\end{array}$ & $\begin{array}{l}\text { Soluble } \\
\text { Collagen } \\
\text { W6 (g) }\end{array}$ & $\begin{array}{c}\% \text { collagen } \\
(\text { w/w of } \\
\text { tissue })= \\
(\mathrm{W} 6 / \mathrm{W} 1) \times 100\end{array}$ \\
\hline $\begin{array}{l}\text { Pacu } \\
\text { Skin }\end{array}$ & 72.04 & & 59.74 & & 51.74 & & 47.17 & & 0.08 & 47.09 & 65.3 \\
\hline
\end{tabular}


bioRxiv preprint doi: https://doi.org/10.1101/2021.02.13.431097; this version posted February 14, 2021. The copyright holder for this preprint (which was not certified by peer review) is the author/funder, who has granted bioRxiv a license to display the preprint in perpetuity. It is made Graphical abstract available under aCC-BY-NC-ND 4.0 International license.

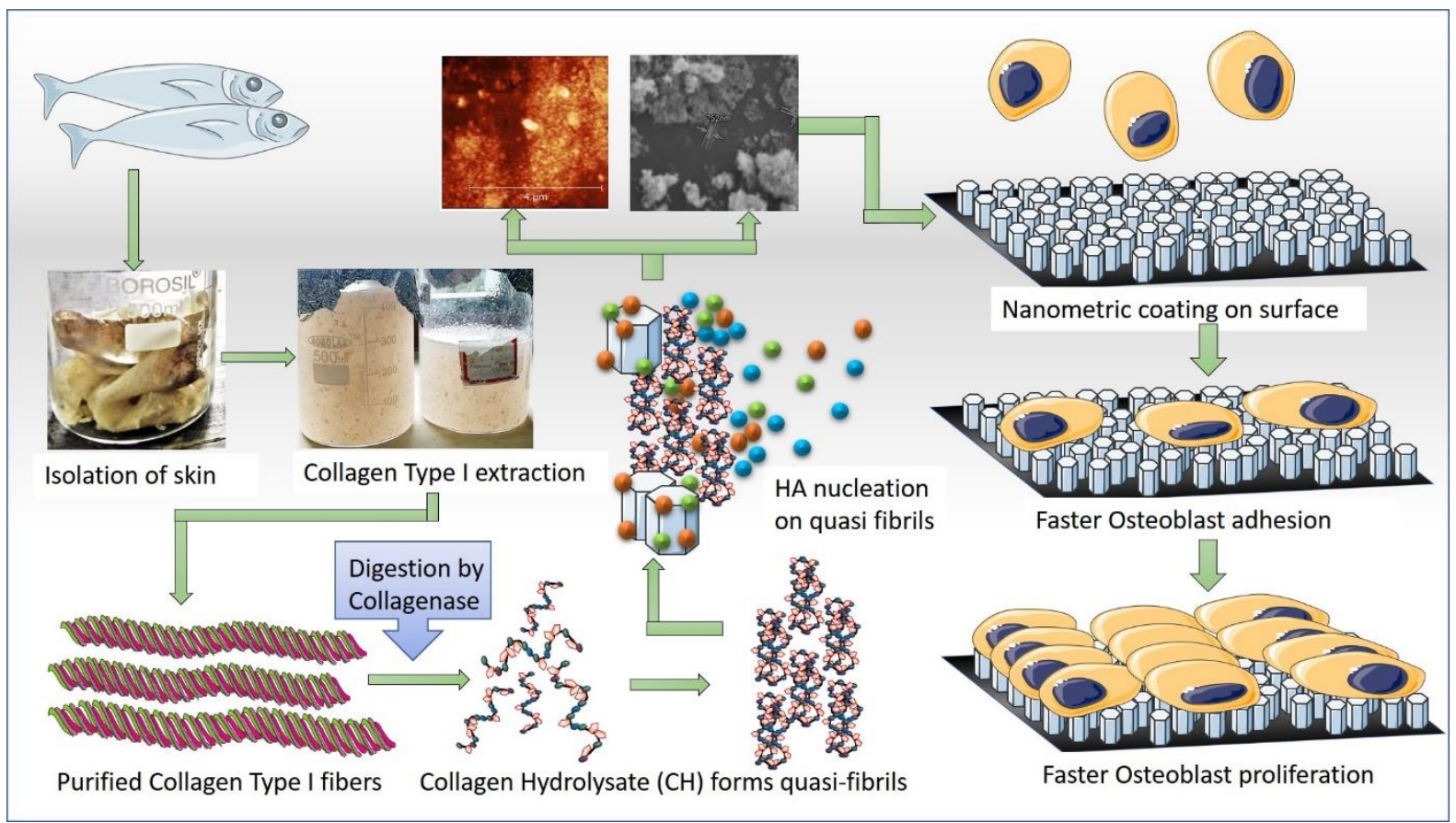


bioRxiv preprint doi: https://doi.org/10.1101/2021.02.13.431097; this version posted February 14, 2021. The copyright holder for this preprint (which was not certified by peer review) is the author/funder, who has granted bioRxiv a license to display the preprint in perpetuity. It is made available under aCC-BY-NC-ND 4.0 International license.

Fig. 1

a.

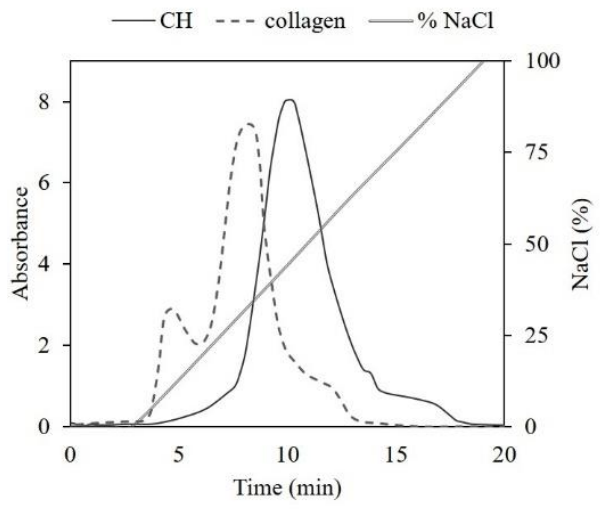

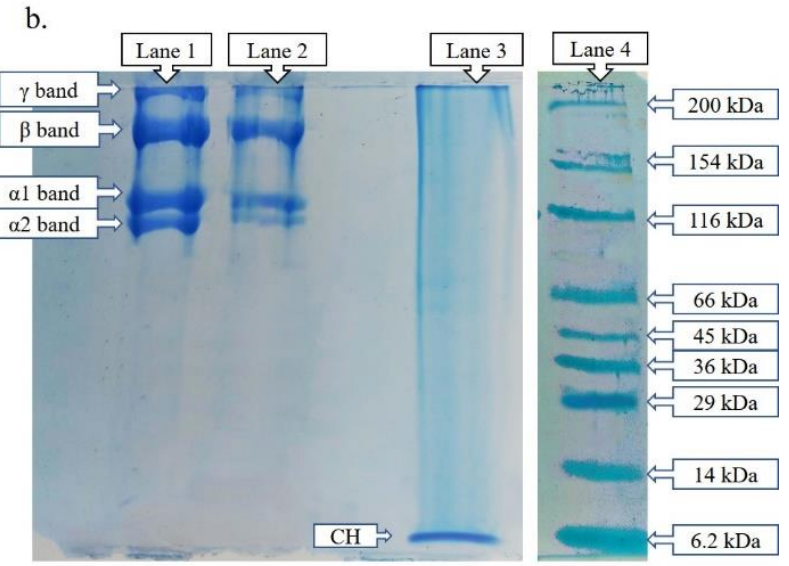

a. Purification of $\mathrm{CH}$ from collagen type 1 by IEC. A shoulder peak at $8.30 \%$ and an intense peak at $43.50 \%$ of $\mathrm{NaCl}$ concentration indicating the presence of aggregated collagen and purified $\mathrm{CH}$ respectively.

b. Electrophoretic profile of isolated collagen (lane 1), rat-tail tendon collagen (lane 2, control), collagen hydrolysate (lane 3) and standard marker (lane 4). 
Fig. 2 available under aCC-BY-NC-ND 4.0 International license.

a.

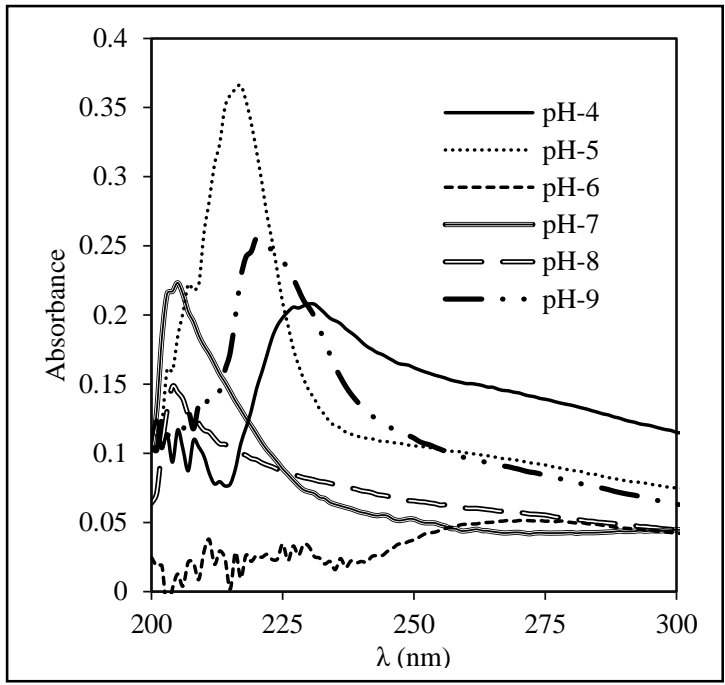

b.

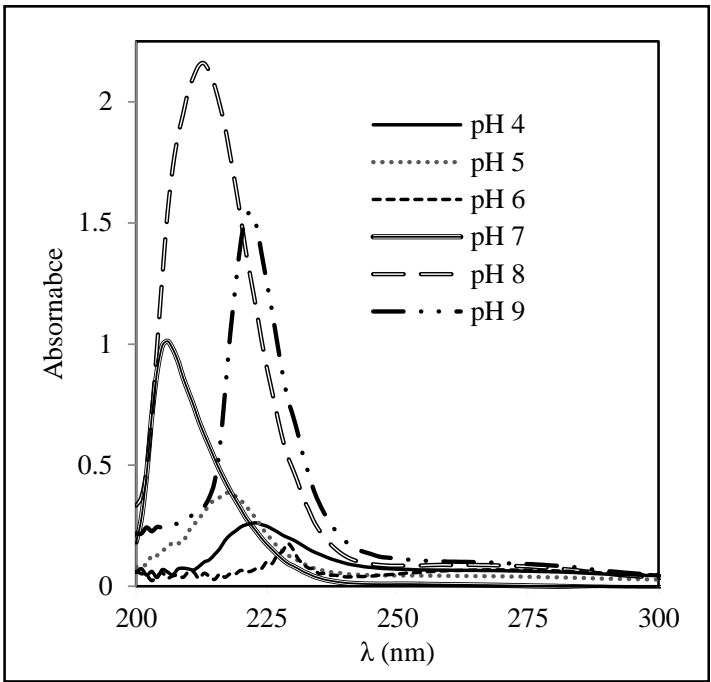

c.

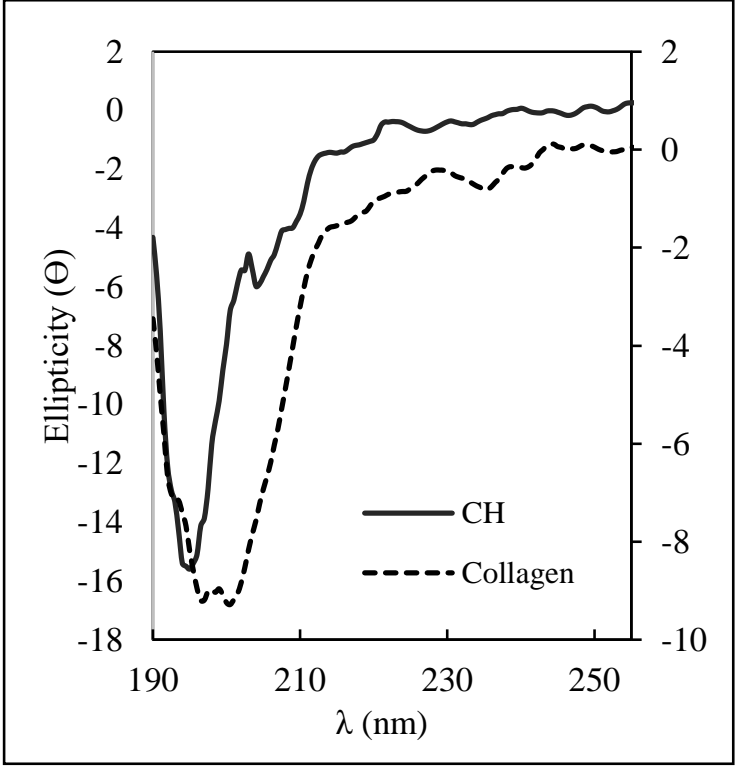

$\mathbf{a}-\mathrm{pH}$-dependent Absorbance profile shift of $\mathrm{CH}$ displaying tendency to self-assemble at neutral and alkaline $\mathrm{pH}$

$\mathbf{b}-\mathrm{pH}$-dependent absorbance profile shift of collagen displaying fibril-formation tendency at $\mathrm{pH} 7$

c - $\mathrm{CD}$ spectra of $\mathrm{CH}$ and collagen at $\mathrm{pH} 7.4$ with the former exhibiting a tendency to form fibrils 
bioRxiv preprint doi: https://doi.org/10.1101/2021.02.13.431097; this version posted February 14, 2021. The copyright holder for this preprint (which was not certified by peer review) is the author/funder, who has granted bioRxiv a license to display the preprint in perpetuity. It is made

Fig. 3 available under aCC-BY-NC-ND 4.0 International license.

a.

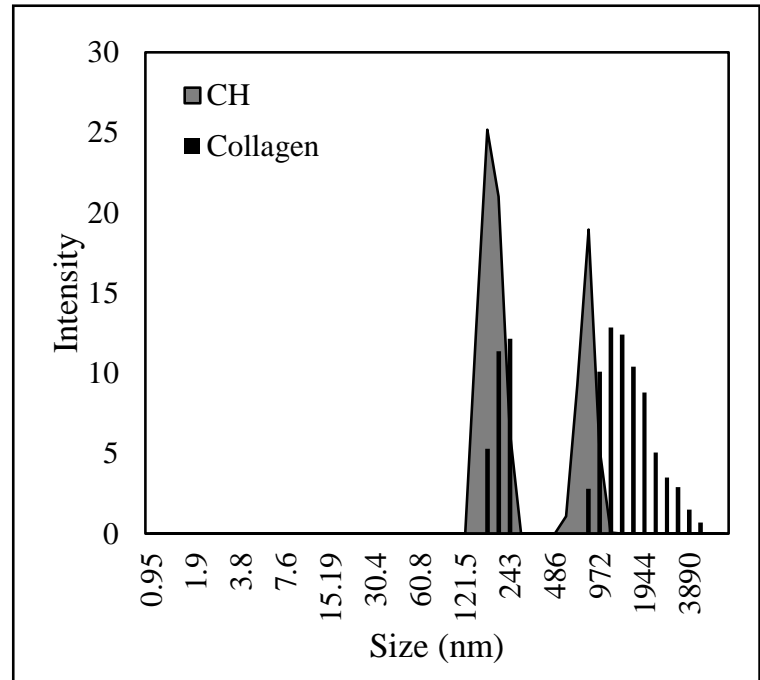

b.

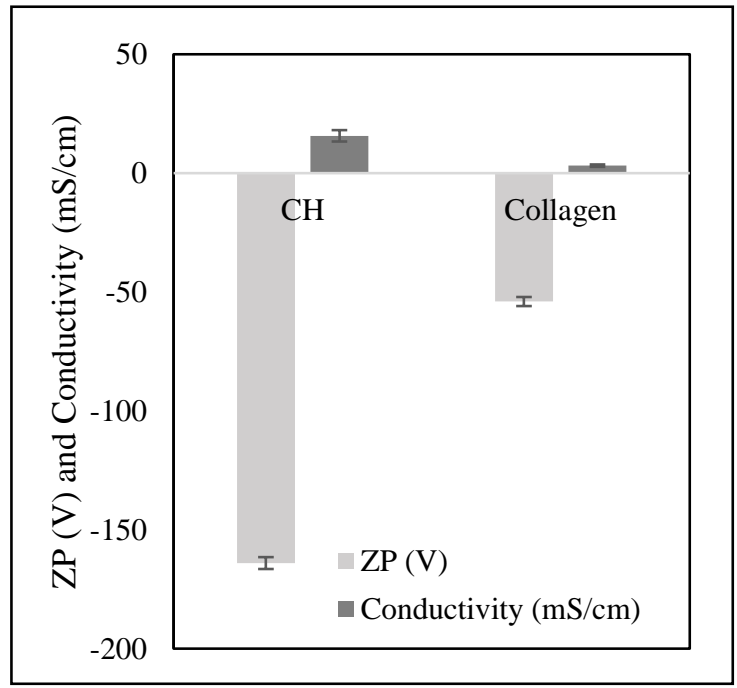

a- Distribution of particle diameter of $\mathrm{CH}$ (grey solid area) compared to collagen (lines). $\mathrm{CH}$ shows a small but definite presence of fibrillar assemblies

$\mathrm{b}-\mathrm{CH}$ displays a greater $\mathrm{ZP}$ and conductivity when compared to collagen 
bioRxiv preprint doi: https://doi.org/10.1101/2021.02.13.431097; this version posted February 14, 2021. The copyright holder for this preprint (which was not certified by peer review) is the author/funder, who has granted bioRxiv a license to display the preprint in perpetuity. It is made available under aCC-BY-NC-ND 4.0 International license.

Fig. 4

a.

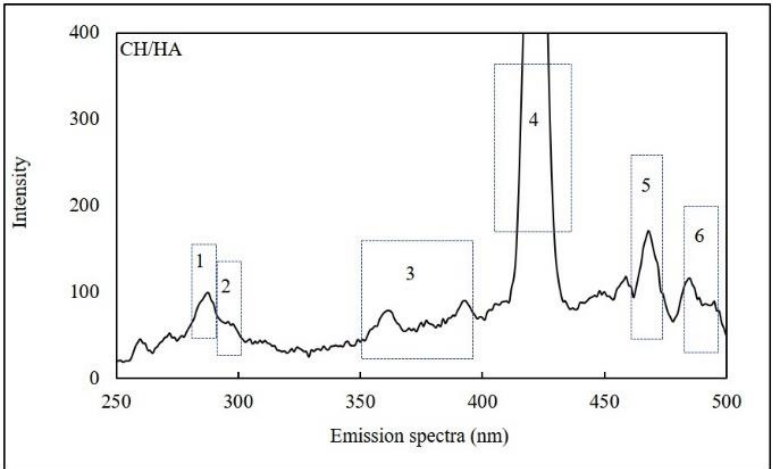

b.

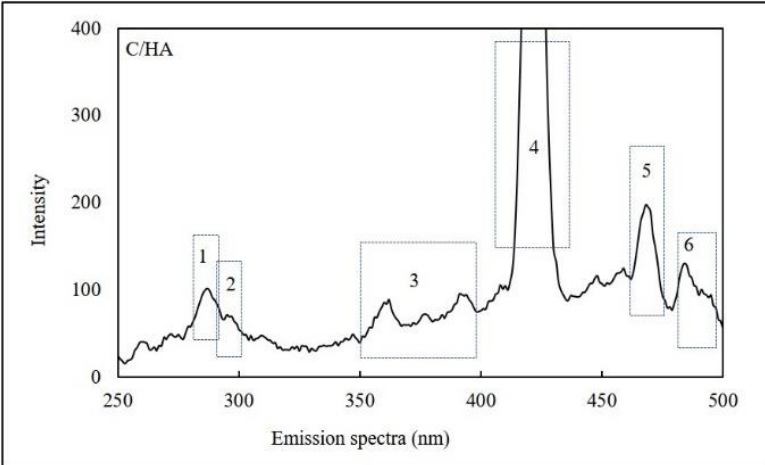

Photo Luminescence profile of a. $\mathrm{CH} / \mathrm{HA} \mathrm{b}$. C/HA displaying peaks of specific amino acid residues and dityrosine crosslinks formed due to HA nucleation. The highlighted peaks display the following amino acid residues (1) Phenylalanine (2) Tyrosine (3) Tyrosine aggregates (4) Dityrosine (5) Tryptophan coupled with histidine (6) Tryptophan 
Fig 5 available under aCC-BY-NC-ND 4.0 International license.

a.

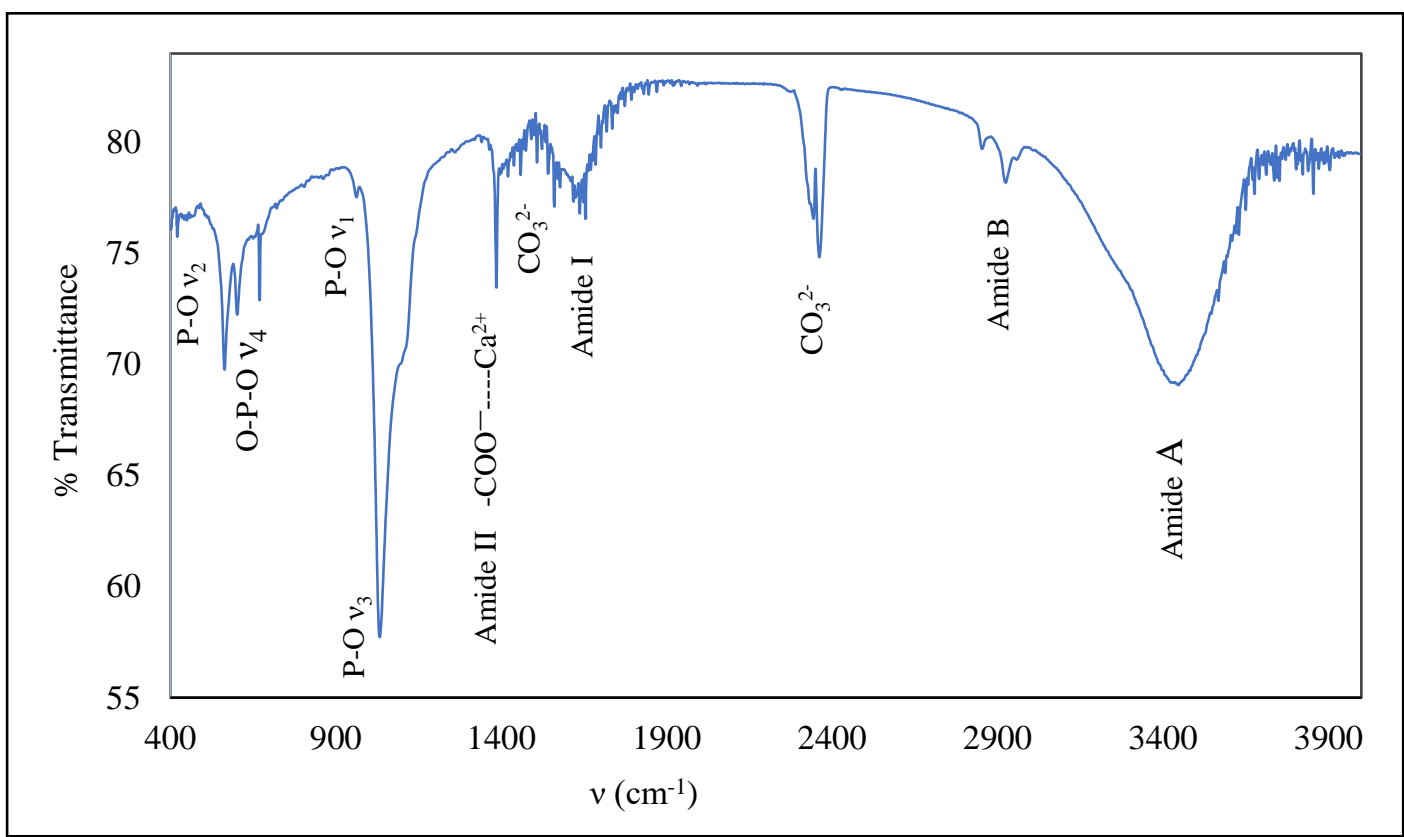

b.

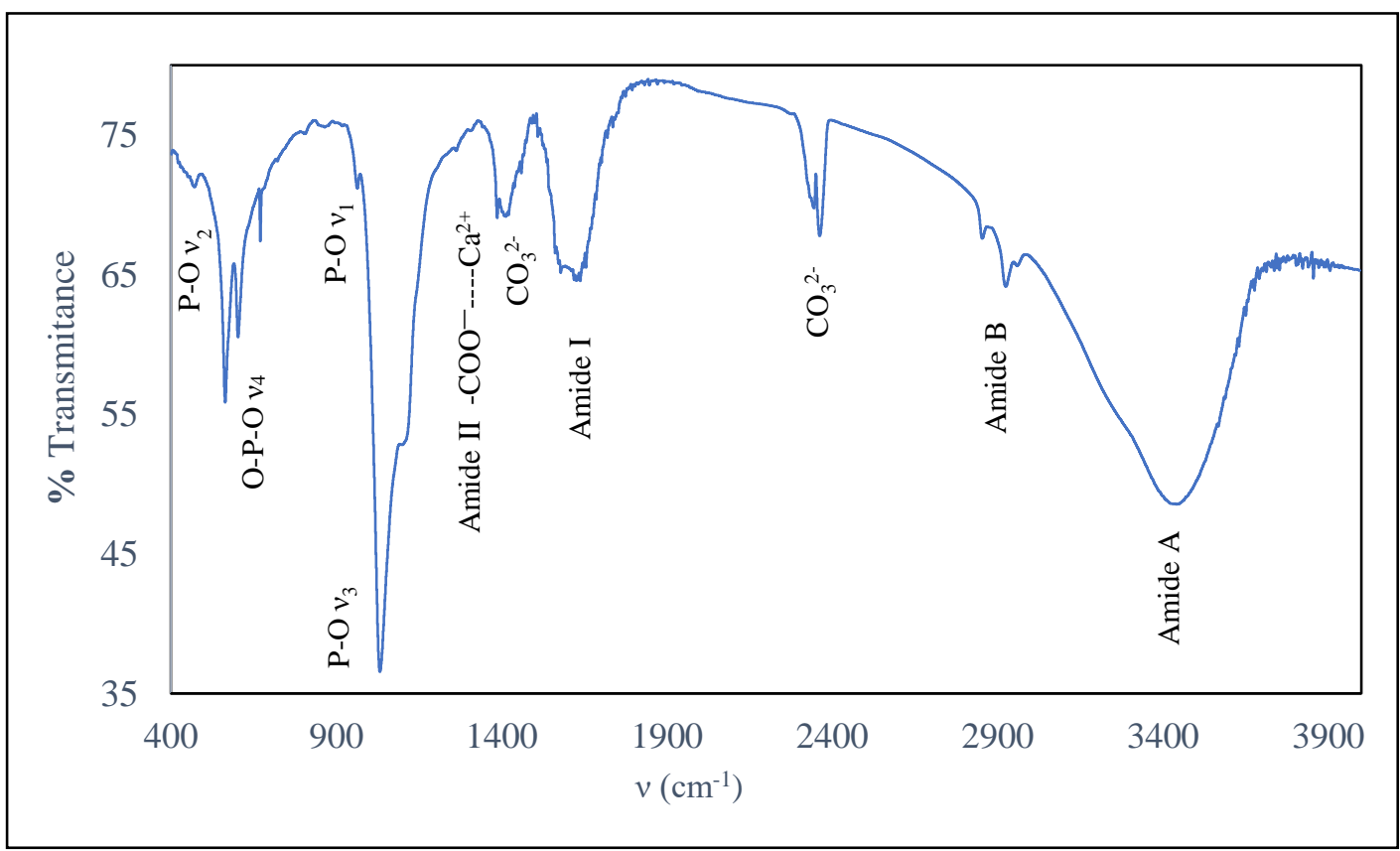

FTIR spectral profile of a. CH/HA b. C/HA exhibiting Amide A, B, I, II and HAspecific bands. $\mathrm{CH} / \mathrm{HA}$ displays an intense peak at $1384 \mathrm{~cm}^{-1}$ and lower Amide II indicating higher mineralization. 
bioRxiv preprint doi: https://doi.org/10.1101/2021.02.13.431097; this version posted February 14, 2021. The copyright holder for this preprint (which was not certified by peer review) is the author/funder, who has granted bioRxiv a license to display the preprint in perpetuity. It is made

Fig. 6 available under aCC-BY-NC-ND 4.0 International license.

a.

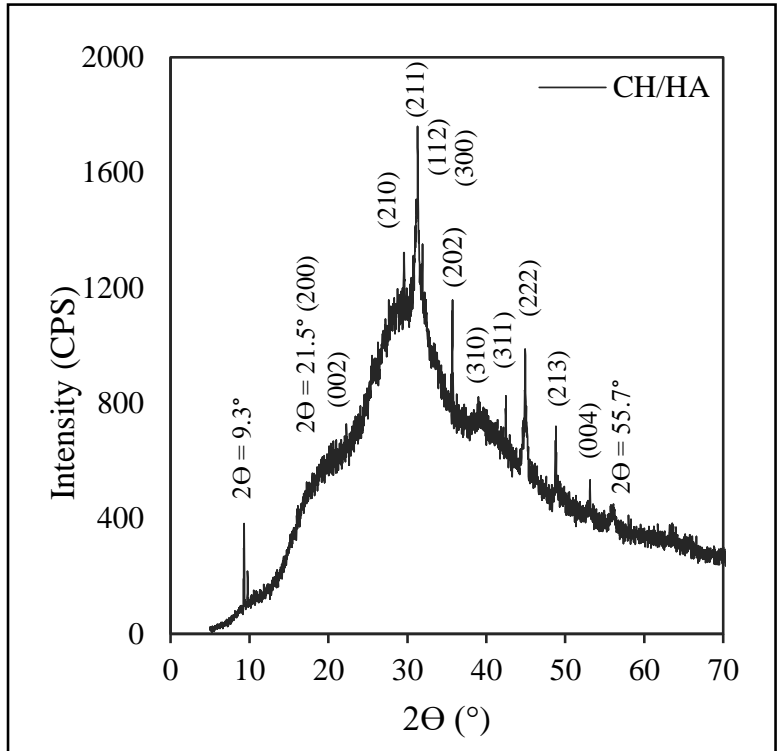

c.

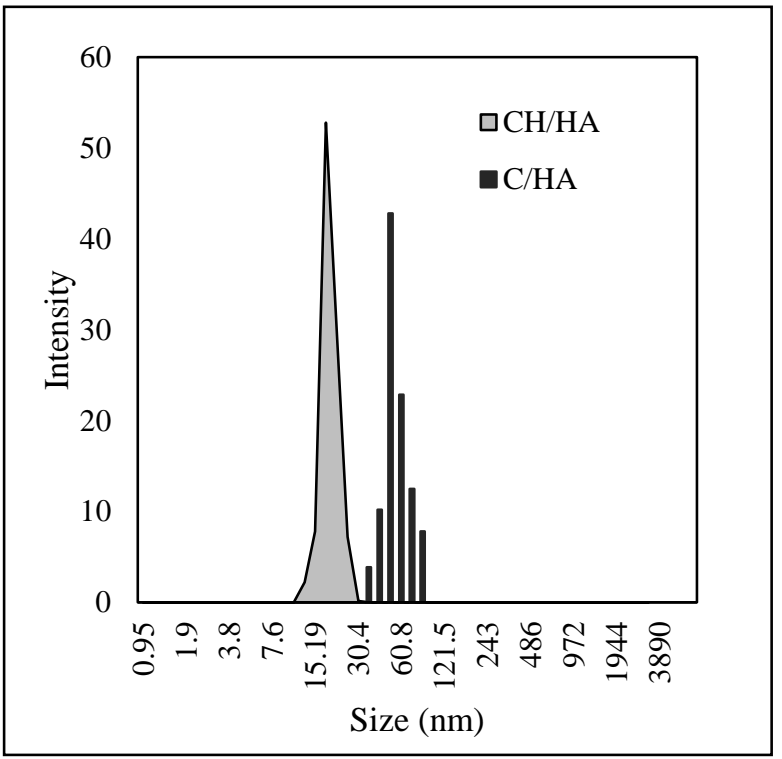

b.

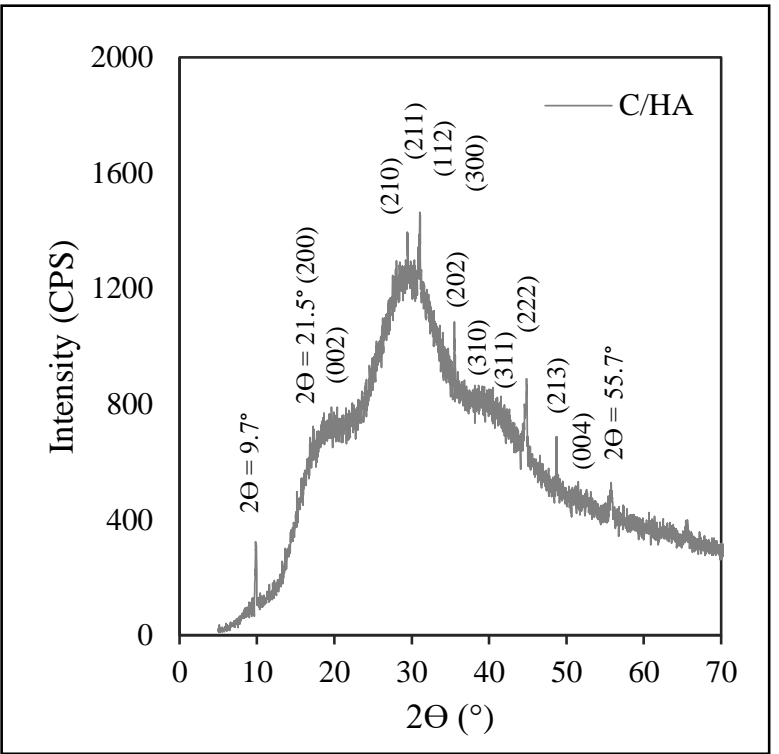

d.

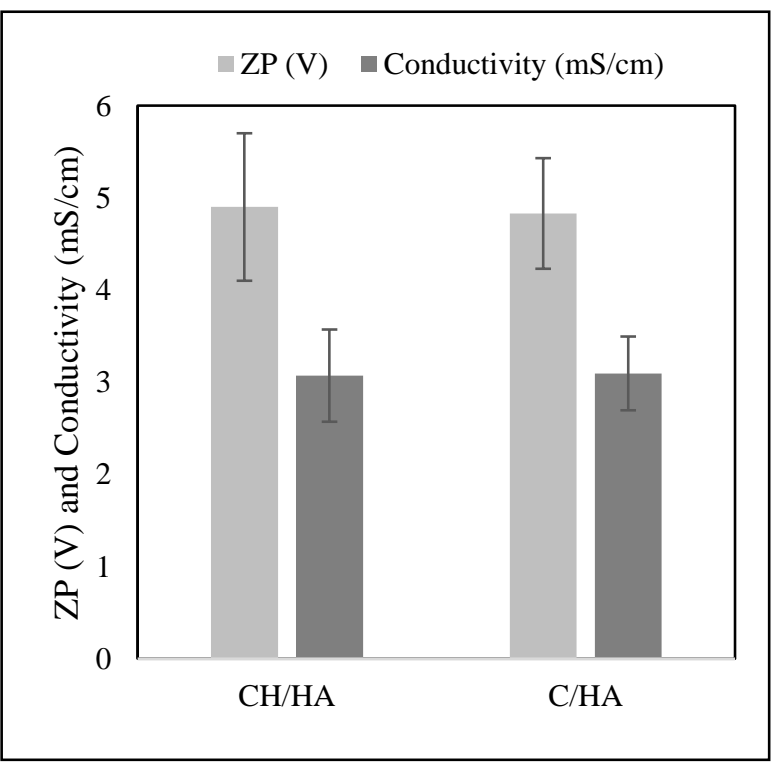

a - XRD spectral profile of $\mathrm{CH} / \mathrm{HA}$ with greater crystallinity

b - XRD spectra of C/HA

c - Particle size distribution as observed by dynamic light scattering. $\mathrm{CH} / \mathrm{HA}$ (grey, solid) displayed an average size of $41.16 \pm 13.21 \mathrm{~nm}$ which was lower than the size distribution of C/HA (lines); $58.2 \pm 18.7 \mathrm{~nm}$.

d- $\mathrm{CH} / \mathrm{HA}$ and $\mathrm{C} / \mathrm{HA}$ displayed a similar $\mathrm{ZP}(\mathrm{V})$ and Conductivity $(\mathrm{mS} / \mathrm{cm})$ value 
Fig. 7 available under aCC-BY-NC-ND 4.0 International license.

a.

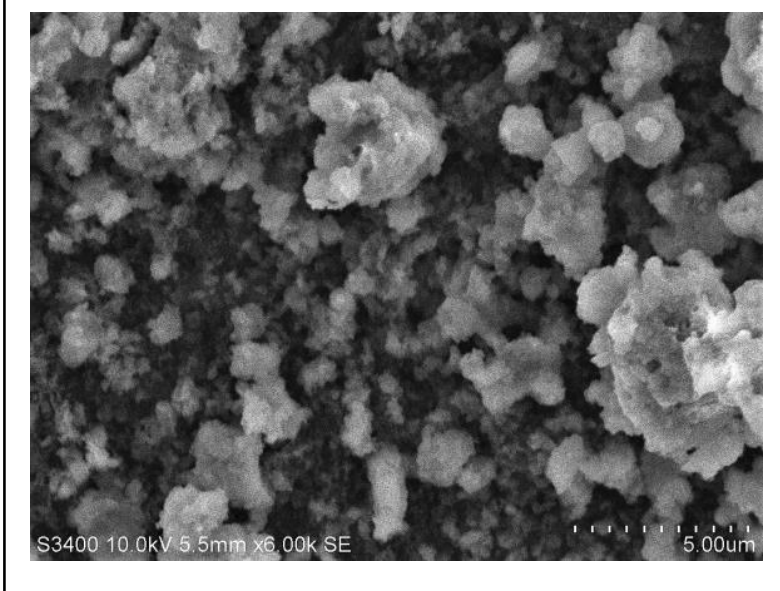

c.

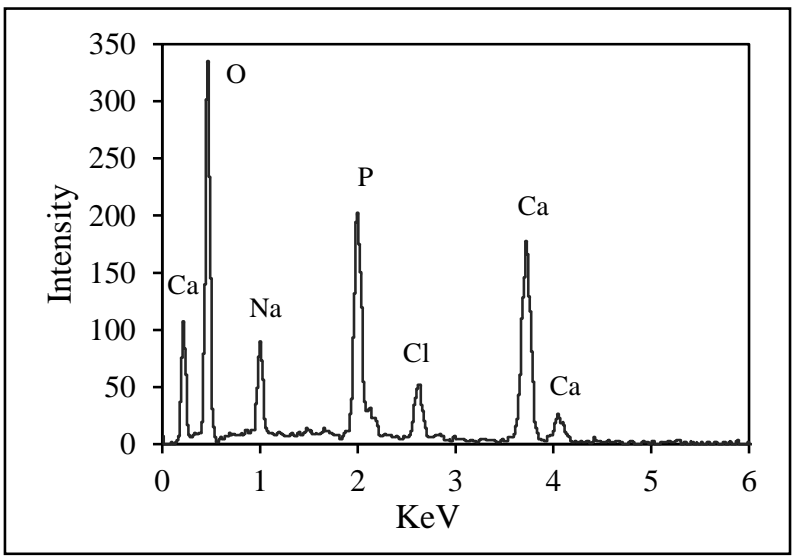

b.

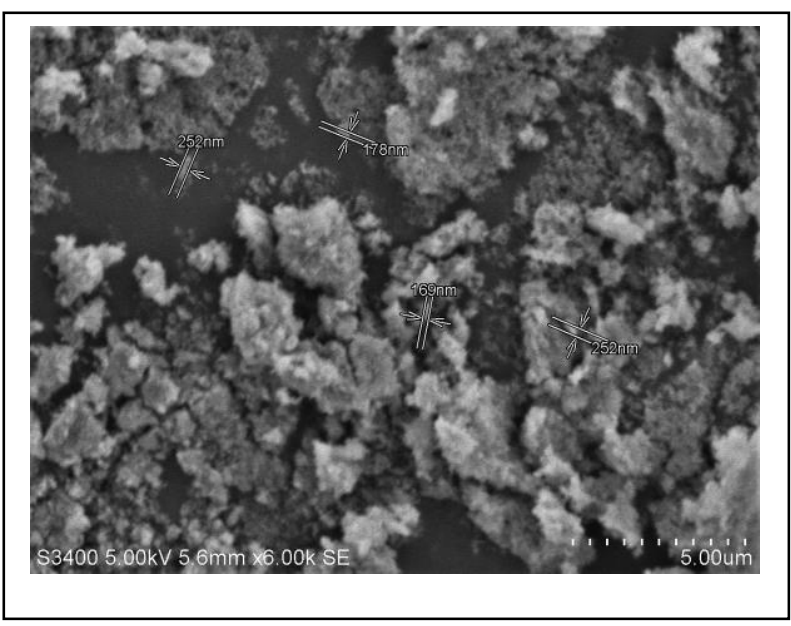

d.

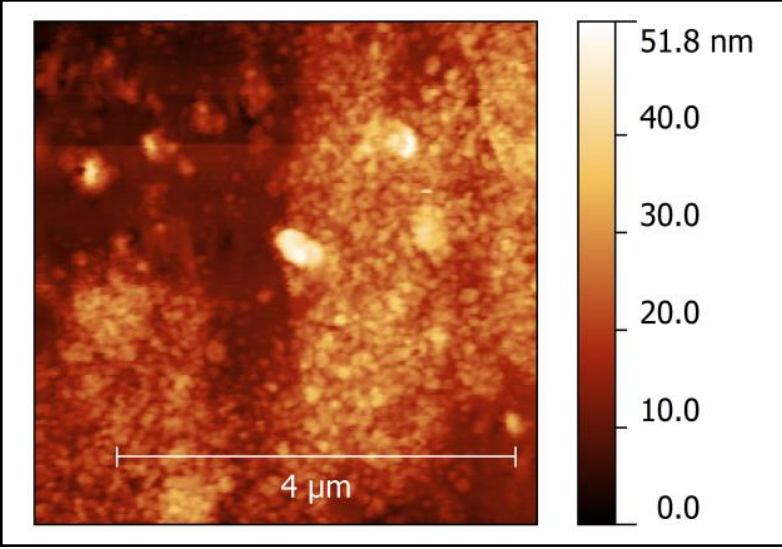

a - SEM image of coated $\mathrm{CH} / \mathrm{HA}$ displaying smaller blooming crystals with the magnification of 1500X. The white dashed line represents a length of $5 \mu \mathrm{m}$.

b - SEM image of coated C/HA with the magnification of $1500 \mathrm{X}$. The white dashed line represents a length of $5 \mu \mathrm{m}$.

c - EDX element analysis of CH/HA displaying a $\mathrm{Ca} / \mathrm{P}$ ratio of 1.78

d - AFM analysis of $\mathrm{CH} / \mathrm{HA}$ displaying the shape and nanophasic size of the HA crystals to be irregular oval-shaped with a height of $48 \pm 6.2 \mathrm{~nm}$. The white line represents a length of $4 \mu \mathrm{m}$. 
bioRxiv preprint doi: https://doi.org/10.1101/2021.02.13.431097; this version posted February 14, 2021. The copyright holder for this preprint (which was not certified by peer review) is the author/funder, who has granted bioRxiv a license to display the preprint in perpetuity. It is made Fig. 8 available under aCC-BY-NC-ND 4.0 International license.

a.

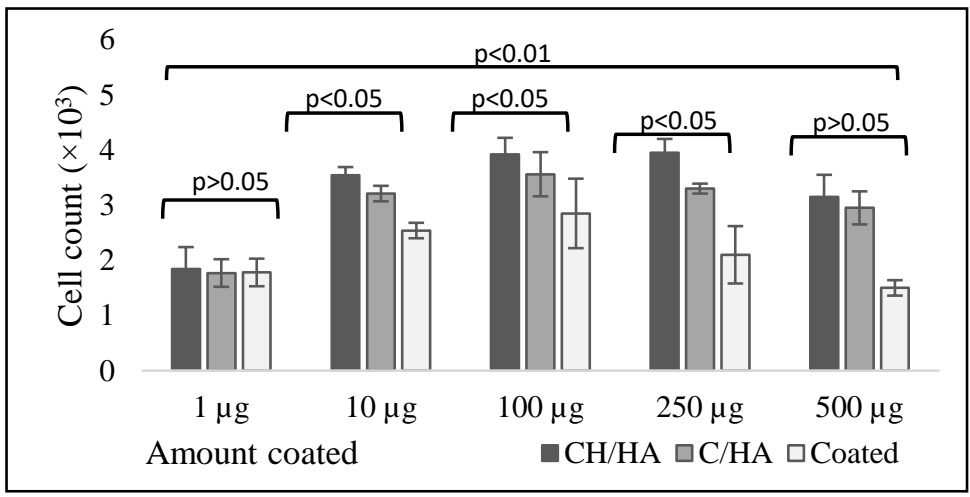

b.

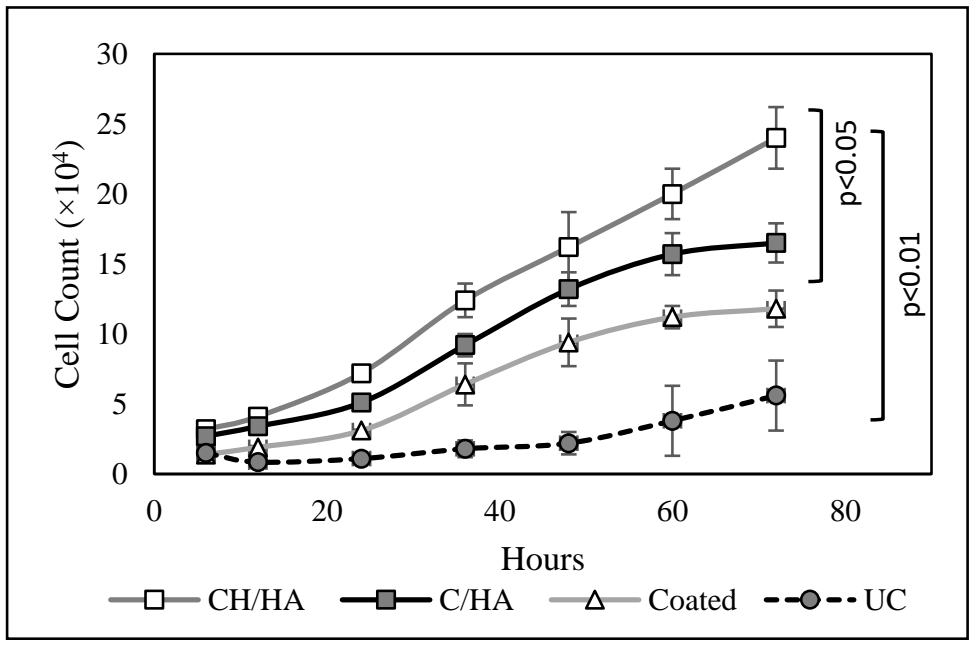

d.

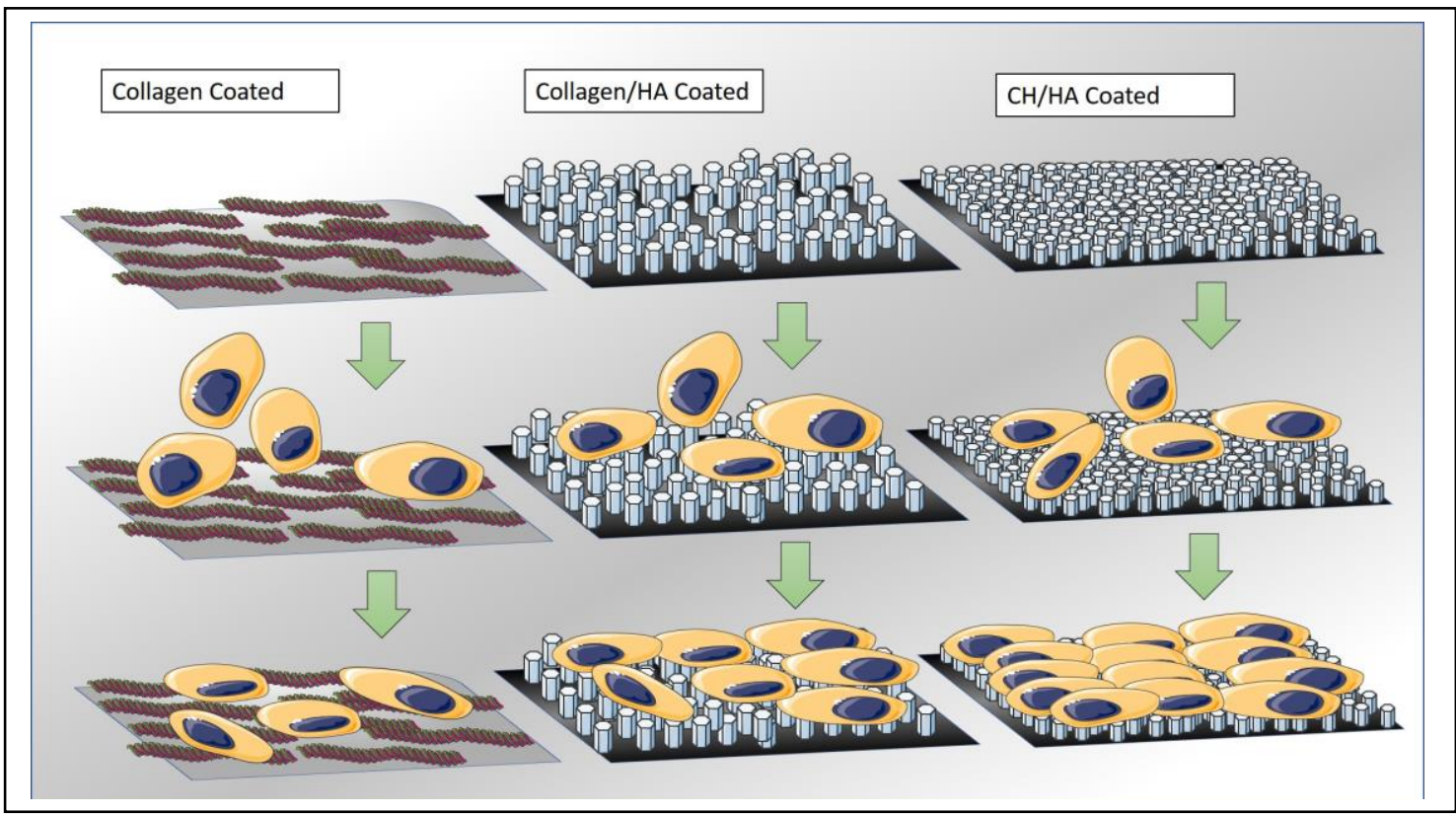

c.
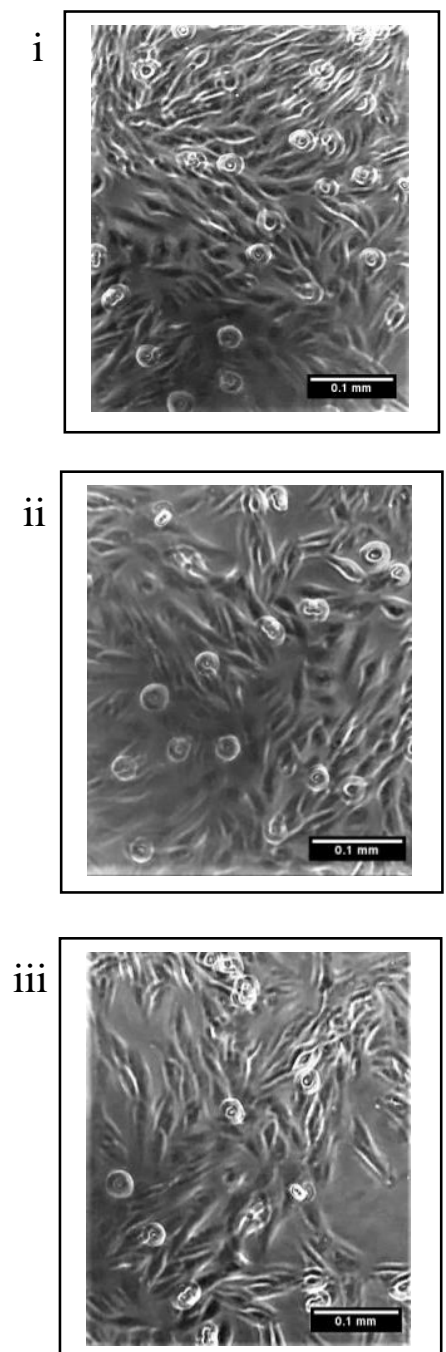
bioRxiv preprint doi: https://doi.org/10.1101/2021.02.13.431097; this version posted February 14, 2021. The copyright holder for this preprint (which was not certified by peer review) is the author/funder, who has granted bioRxiv a license to display the preprint in perpetuity. It is made

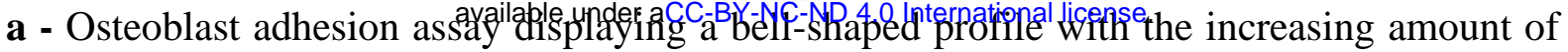
coating material. The significance values are displayed in the graph.

b - Cell proliferation assay displaying a significantly higher cell growth when cultured in the presence of $\mathrm{CH} / \mathrm{HA}$ when compared to $\mathrm{C} / \mathrm{HA}$.

c - Photomicrographs representing MG63 growth on collagen-coated (I), CH/HA coated (II), $\mathrm{C} / \mathrm{HA}$ coated (III) collagen coated wells. The white line represents a distance of $0.1 \mathrm{~mm}$.

d - An illustration depicting the faster adhesion and greater proliferation of MG63 on the $\mathrm{CH} / \mathrm{HA}$ coated surface when compared to $\mathrm{C} / \mathrm{HA}$ and collagen-coated surfaces due to the smaller size of $\mathrm{CH} / \mathrm{HA}$ making it more 'osteophilic'. 